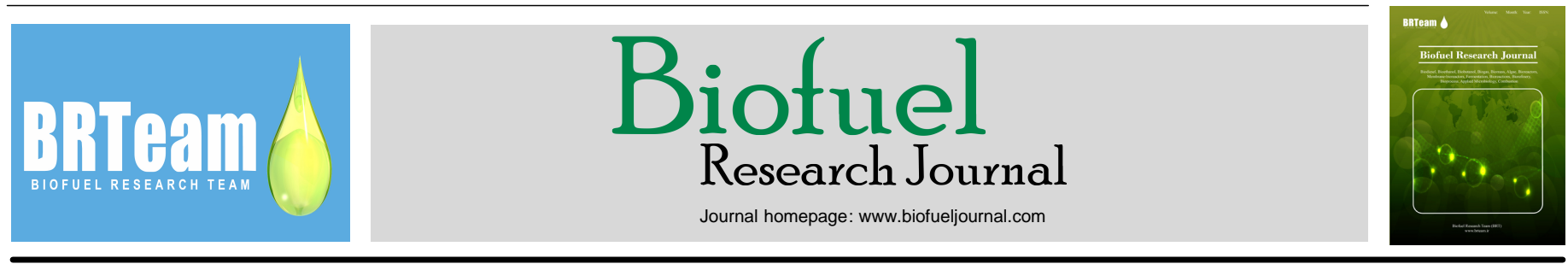

Review Paper

\title{
Key issues in estimating energy and greenhouse gas savings of biofuels: challenges and perspectives
}

\author{
Dheeraj Rathore ${ }^{1, \dagger}$, Abdul-Sattar Nizami ${ }^{2, \dagger}$, Anoop Singh $^{3}$, Deepak Pant ${ }^{4, *}$ \\ ${ }^{1}$ School of Environment and Sustainable Development, Central University of Gujarat, Gandhinagar-382030, Gujarat, India. \\ ${ }^{2}$ Solid Waste Research Group, Center of Excellence in Environmental Studies (CEES), King Abdul Aziz University, P.O Box: 80216, Jeddah 21589, Saudi \\ Arabia. \\ ${ }^{3}$ Government of India, Ministry of Science and Technology, Department of Scientific and Industrial Research (DSIR), Technology Bhawan, New Mehrauli \\ Road, New Delhi- 110016 India. \\ ${ }^{4}$ Separation and Conversion Technologies, VITO-Flemish Institute for Technological Research, Boeretang 200, 2400 Mol, Belgium.
}

\section{HIGHLIGHTS}

$>$ Land-use and land-use changes may overestimate the biofuel sustainability.

$>$ Environmental and social acceptability is essential in making biofuel-support policies.

$>$ Different biomass result in different energy

balances and GHG savings of biofuels.

$>$ Sustainable biomass or non-food biomass can

increase biofuel sustainability ranking.

\section{GRAPHICAL ABSTRACT}

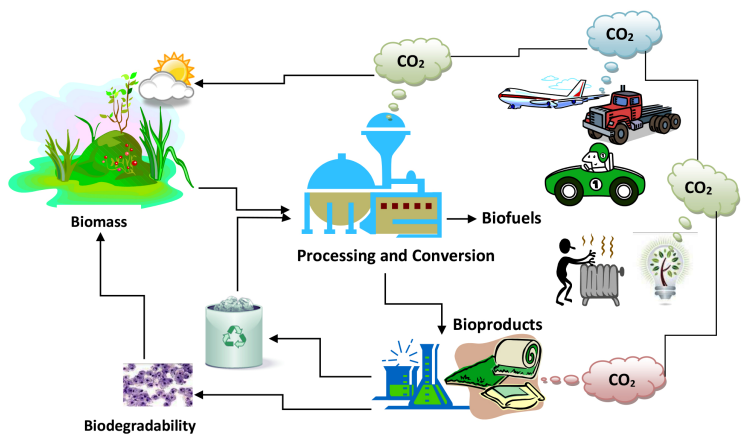

\section{ARTICLE INFO}

\section{Article history:}

Received 5 April 2016

Received in revised form 5 May 2016

Accepted 9 May 2016

Available online 1 June 2016

\section{Keywords:}

Energy balance

Greenhouse gas (GHG) balance

Biofuels

Sustainability

Life cycle assessment (LCA)

\begin{abstract}
The increasing demand for biofuels has encouraged the researchers and policy makers worldwide to find sustainable biofuel production systems in accordance with the regional conditions and needs. The sustainability of a biofuel production system includes energy and greenhouse gas (GHG) saving along with environmental and social acceptability. Life cycle assessment (LCA) is an internationally recognized tool for determining the sustainability of biofuels. LCA includes goal and scope, life cycle inventory, life cycle impact assessment, and interpretation as major steps. LCA results vary significantly, if there are any variations in performing these steps. For instance, biofuel producing feedstocks have different environmental values that lead to different GHG emission savings and energy balances. Similarly, land-use and land-use changes may overestimate biofuel sustainability. This study aims to examine various biofuel production systems for their GHG savings and energy balances, relative to conventional fossil fuels with an ambition to address the challenges and to offer future directions for LCA based biofuel studies. Environmental and social acceptability of biofuel production is the key factor in developing biofuel support policies. Higher GHG emission saving and energy balance of biofuel can be achieved, if biomass yield is high, and ecologically sustainable biomass or non-food biomass is converted into biofuel and used efficiently.
\end{abstract}

(C) 2016 BRTeam. All rights reserved.

* Corresponding author at: Tel.: +32 14336969

E-mail address: deepak.pant@ vito.be ; pantonline@gmail.com

$\uparrow$ Ihese authors contributed equally.

Please cite this article as: Rathore D., Nizami A.S., Singh A., Pant D. Key issues in estimating energy and greenhouse gas savings of biofuels: challenges and perspectives. Biofuel Research Journal 10 (2016) 380-393. DOI: 10.18331/BRJ2016.3.2.3 


\section{Contents}

1. Introduction.

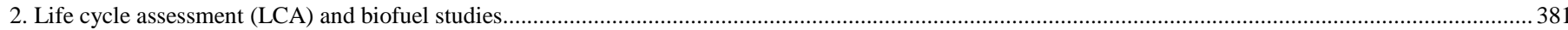

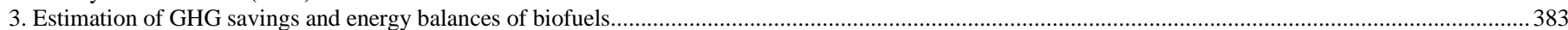

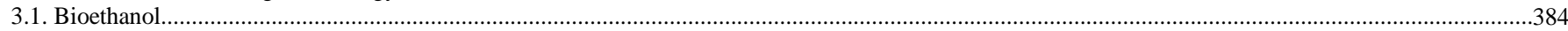

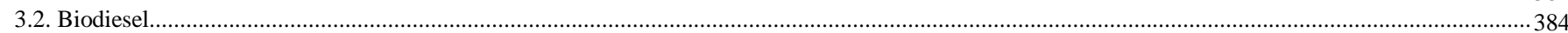

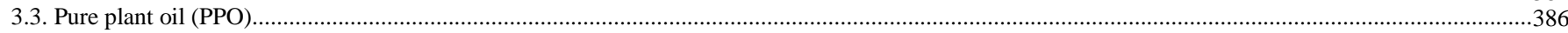

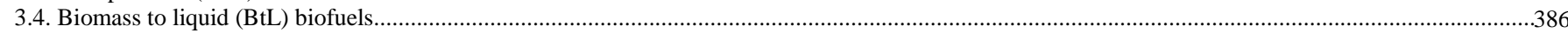

3.5. Biomethane

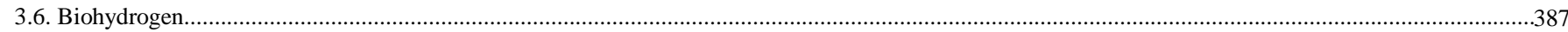

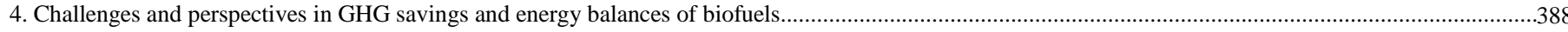

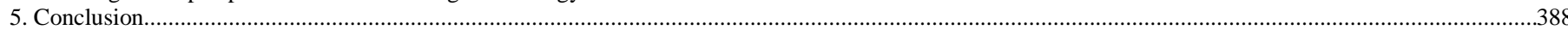

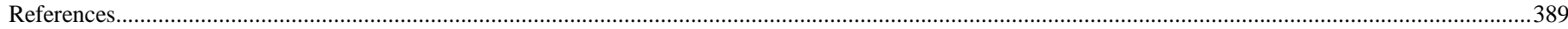

\begin{tabular}{|ll|}
\hline Abbreviations & \\
AD & Anaerobic digestion \\
ALT & Atmospheric life time \\
BtL & Biomass to liquid \\
CG & Clean gasoline \\
CHP & Combined heat and power \\
FER & Fossil energy ratio \\
FFV & Flexible fuel vehicles \\
F-T & Fischer-Tropsch \\
GHG & Greenhouse gas \\
GWP & Global warming potential \\
HHV & High heating value \\
LCA & Life cycle assessment \\
MEC & Microbial electrolysis cell \\
NER & Net energy ratio \\
NEY & Net energy yield \\
OFMSW & Organic fraction of municipal solid waste \\
PPO & Pure plant oil \\
TtW & Tank to wheel \\
WtT & Well to tank \\
WtW & Well to wheel \\
\hline
\end{tabular}

\section{Introduction}

Biofuels are getting significant attention worldwide due to depletion of fossil fuels and concerns regarding climate change (Popp et al., 2016; Khanna et al., 2010). They are recognized for their potential role in reducing greenhouse gas (GHG) emissions and providing energy security (Fig. 1). However, their sustainability is still under an intense debate due to different methodologies, biomass sources, land-use and land-use changes, fuel-blends, and end-use applications (Sims et al., 2010; Glenister and Nunes, 2011; Lankoski et al., 2011). Biofuels exist in solid, liquid, and gas forms and are derived from different biomass sources such as perennial crops, sugarcane, and corn starch as well as agricultural and forestry residues and organic fraction of industrial and municipal wastes (Nizami and Ismail, 2013; Ouda et al., 2016). Liquid biofuels are used as transportation fuel and for electricity generation through turbines and engines (Korres et al., 2011; Singh et al., 2012). The gaseous biofuels are also used as transportation fuel and for electricity generation using specially-designed direct and indirect turbineequipped plants (Gnansounou et al., 2008a; Sadaf et al., 2016). While, solid biofuels are used in power plants instead of coal as fuel briquettes or pellets (Singh et al., 2010a; Nizami et al., 2015a and b).

Biofuels produced by exploiting fertile lands are criticized due to environmental, social, and economic issues (Sharma et al., 2012). According to Mukherjee et al. (2011), the issues of land-use and high food and animal feed prices are associated with biofuels that are produced using fertile lands. Moreover, negative impacts on forests and grasslands, loss of biodiversity due to large mono-cropped fields, water scarcity and pollution, and air quality degradation are often associated with such biofuels (Doornbosch and Steenblik, 2007; Fargione et al., 2008; Gnansounou et al., 2008b). Therefore, biofuels produced from non-food biomass sources such as corn stover, cereal straw, sugar cane bagasses, perennial grasses, forestry and agricultural wastes, and municipal and industrial organic wastes are receiving preferences (Searchinger et al., 2008). However, such biofuels are not yet produced at a commercial scale, but can influence GHG savings through land-use changes. For instance, biofuels from algae feedstock, if ever produced in an economically-viable manner, can potentially address most of the biofuels-related issues (Sander and Murthy, 2010; Singh et al., 2012).

Biofuels can be beneficial by reducing GHG emissions to keep climate-change impacts within the limits societies could be able to cope with. However, the benefits of biofuels largely depend on the whole life cycle of biofuel production, as the environmental ranking of biofuels based on GHG savings and energy balances vary with measuring methods, system boundary, land-use and land-use changes, functional unit and allocation methods (Kauffman and Hayes, 2013). All these variables and anticipation in results require comprehensive studies on biofuel production systems (Menichetti and Otto, 2009). Therefore, estimating GHG savings and energy balances of biofuels is not only critical from their sustainability point of view, but also is a challenging task (Singh et al., 2010b). Various models or life cycle assessment (LCA) tools are used to explain the results of biofuel studies that are either policy oriented or related to the process or product design or operation (Hong et al., 2013).

LCA is a cradle-to-grave analysis for the energy and environmental impacts of a product, process, or pathway. This is mandatory by the directive of EU (Directive 2009/28/EC) to employ the LCA method to reduce $\mathrm{CO}_{2}$ emissions by $35 \%$ until 2017, by $50 \%$ until 2018 and by $60 \%$ after 2018 (EC-Directive, 2009). The energy efficiency of a biofuel is presented as a ratio of the amount of energy obtained from the fuel to the amount of fossil fuel energy required in its production process (Davis et al., 2008). While, the estimation of energy balances includes both the life cycle energy efficiency of biofuels and the savings from fossil fuels. According to Gnansounou et al. (2009), the inclusion of fossil fuel saving is critical with respect to the replacement efficiency of biofuels with fossil fuels.

The available scientific literature is mainly focused on bioethanol and biodiesel as being the most prominent biofuels. While, the other biofuel resources and systems are more or less ignored in terms of their sustainability (Singh et al., 2010b; Korres et al., 2011; Mukherjee et al., 2011; Sharma et al., 2012). Moreover, there is a strong need to address the key challenges in estimating the GHG savings and energy balances of biofuels along with their possible solutions. Therefore, this review paper aims to examine the various biofuel production systems for their GHG savings and energy balances, relative to conventional fossil fuels. The key issues and future directions for LCA based biofuels studies, especially on estimating GHG savings and energy balances are highlighted.

\section{Life cycle assessment (LCA) and biofuel studies}

LCA is a well-known internationally recognized methodology to evaluate environmental performance of any processes, products or pathways along with their whole or partial life cycle (Gnansounou et al., 2008a). The procedures for LCA are explained in ISO 14040-series (Fig. 2). Numerous studies on the LCA of biofuels have been reported by various researchers with different scope, accuracy, consistency level, transparency, and framework. Scope and goal of LCA are the two important steps, on which system definition and system boundary depend. The goal may be based on an operation, design, or policy (Menichetti and 


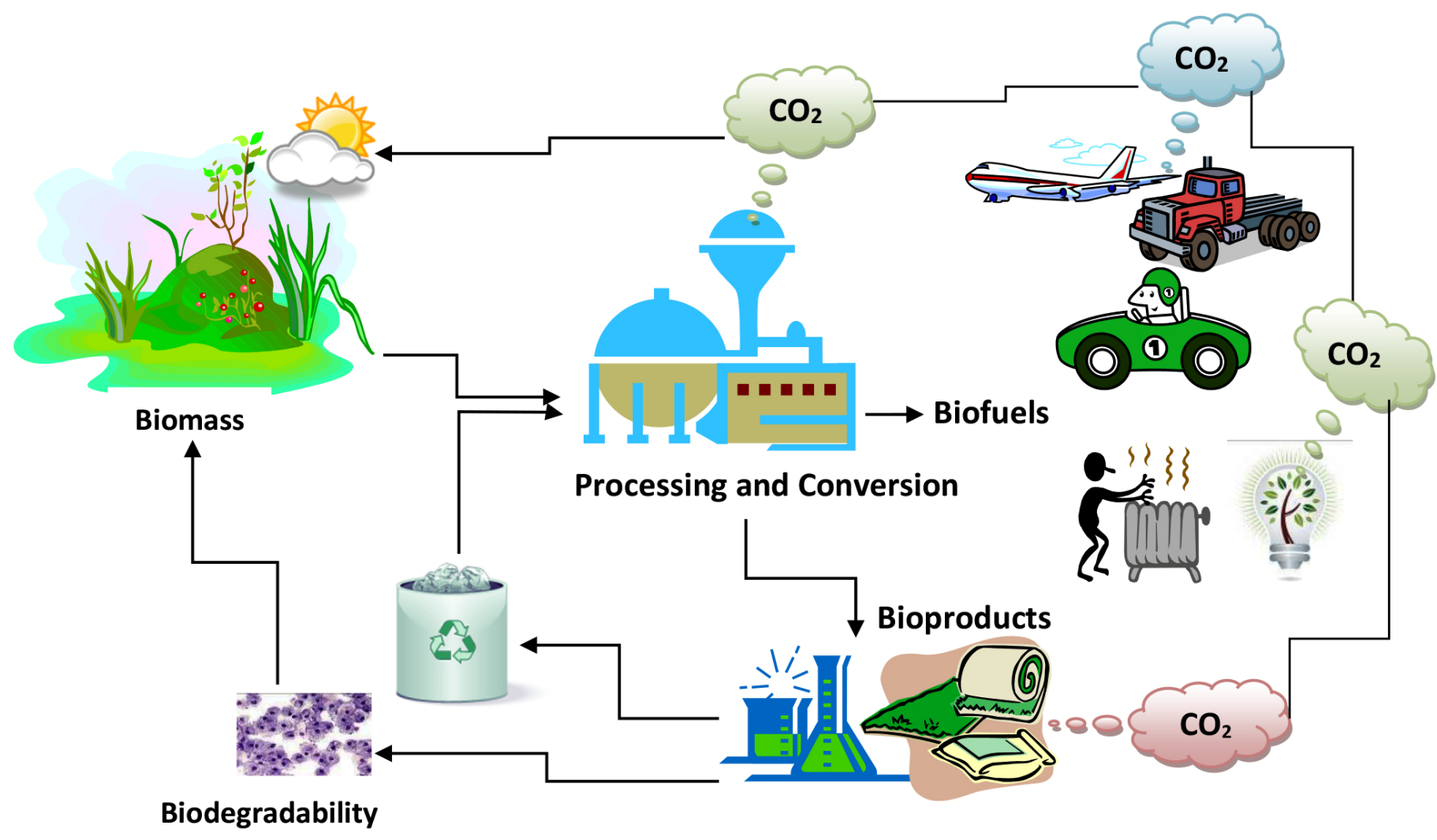

Fig.1. The life cycle of biomass to biofuels and bioproducts.

Otto, 2009). In case of operation and design improvement, the definition of the system should be more comprehensive. While, a simple flowchart of biofuel pathways can describe the policy purpose (Gnansounou et al., 2009). In case of policy as an integral part of LCA framework, the boundary of the system should be adopted according to the purpose. For example, if bioethanol is compared using a well to tank (WtT) approach, LCA results have no impacts on fuel combustion in the engine. However, the situation will change, if the comparison is carried out for the same biofuel with various fossil fuels or their blends (Gnansounou et al., 2008a).

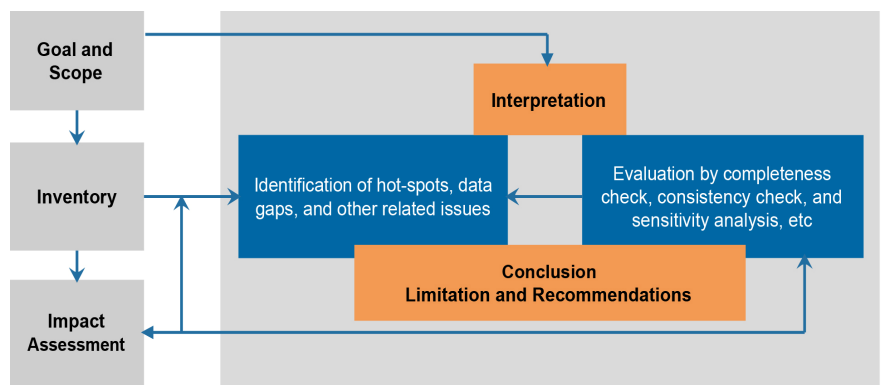

Fig.2. The LCA methodological framework.

Carbon dioxide $\left(\mathrm{CO}_{2}\right)$, water vapours, methane $\left(\mathrm{CH}_{4}\right)$, sulphur hexafluoride, chlorofluorocarbons, nitrous oxide $\left(\mathrm{N}_{2} \mathrm{O}\right)$, hydrofluorocarbons, and perfluorocarbons are considered as major GHG contributors (Cherubini and Strømman, 2011). However, for GHG savings of biofuel, only anthropogenic sources are considered (Nizami and Ismail, 2013). Moreover, $\mathrm{CO}_{2}, \mathrm{CH}_{4}$, and $\mathrm{N}_{2} \mathrm{O}$ are taken into account during LCAs, as their origin could be either fossil or biogenic based (IPCC, 2011). Atmospheric life time (ALT) and its potential are the two factors based on which, GHG effect and global warming are described over a defined timescale. The reference for GHG is $\mathrm{CO}_{2}$, and 1 is its value for global warming potential (GWP) that is taken for all time periods, including anthropogenic and radiative forcing. $\mathrm{CH}_{4}$ has an ALT of 9 for 15 years and has a GWP of 84 for 20 years, 28 for 100 years. The other major GHG contributors like $\mathrm{N}_{2} \mathrm{O}$ has a GWP of 264 for 20 years, 265 for 100 years (Gnansounou et al., 2008a; Myhre et al., 2013). Most of the LCA studies follow the IPCC guidelines to take reference time of 100 years (Gnansounou et al., 2009; IPCC, 2011).

When comparison is made for a biofuel with fossil fuel, it is critical to select the same applicable service. For instance, in case of mobility applications, researchers use $1 \mathrm{MJ}$ of fuels compared (e.g., E5 and gasoline) as a functional unit or choose $1 \mathrm{kWh}$ of brake power produced by the fuels compared as functional unit (Rathore et al., 2013). Many studies concluded that E5 consumption in litres is different than the consumption of gasoline for the same service (e.g., for $100 \mathrm{~km}$ distance travelled). Therefore, less than $1 \mathrm{MJ}$ of E5 is compared with $1 \mathrm{MJ}$ of gasoline (Gnansounou et al., 2008a). The biofuel process comparison is carried out with a certain base line or reference system in order to evaluate the GHG emission savings. For this purpose, most of the LCA based studies use fossil fuels like diesel or gasoline as a reference system. The different results of such studies are due to variations in GHG savings of biofuel co-products that are used to replace the existing fossil fuel products (Singh et al., 2011 and 2012).

In LCA, different allocation methods such as physical and economical allocation are used to divide the environmental burden of a process or product when several functions reflect the same process. Therefore, allocation methods vary by mass (wet or dry), energy content, system expansion, economic value, and carbon content. The recommended 
Table 1.

Biofuels classification (Pande and Bhaskarwar, 2012).

\begin{tabular}{|c|c|c|c|}
\hline Biofuels & First generation biofuels & Second generation biofuels & Third generation biofuels \\
\hline Features & $\begin{array}{l}\text { Fuels produced from raw materials in competition with food and feed } \\
\text { industry }\end{array}$ & $\begin{array}{l}\text { Fuels produced from non-food crops (energy crops) or raw } \\
\text { materials based on waste residues }\end{array}$ & $\begin{array}{l}\text { Fuels produced using aquatic } \\
\text { microorganisms like algae }\end{array}$ \\
\hline Examples & $\begin{array}{l}\text { Bioethanol from sugarcane, sugar beet and starch (corn and wheat), } \\
\text { biodiesel from oil based crop like rape seed, sunflower, soybean, palm } \\
\text { oil, and waste edible oils- and starch-derived biogas }\end{array}$ & $\begin{array}{l}\text { Biogas from waste and residues, bioethanol and biohydrogen from } \\
\text { lignocellulosic materials like residues from agriculture, forestry } \\
\text { and industry and fuels from energy crops such as sorghum }\end{array}$ & $\begin{array}{l}\text { Biodiesel produced using algae and } \\
\text { algal hydrogen }\end{array}$ \\
\hline
\end{tabular}

allocation method of ISO 14040-series is system expansion, which is difficult to implement as results rely on the reference system (Singh et al., 2010a). If the direct land-use changes especially the carbon storage, is missing in the consideration of previous carbon storage, it may overestimate the performance of a biofuel. The carbon storage is positive when feedstock is produced from a degraded soil (Gnansounou et al., 2008a). There is a large difference between the data provided from existing database and the data obtained from a region, site, or country. Therefore, if the cost of supplementary information is affordable, then the default data should be used with precaution, otherwise data generalization should be avoided (Singh et al., 2010b).

Various sensitivity analysis and scenarios are used to evaluate the sensitivity in LCA studies. Ecoinvent ${ }^{\circledR}$ or SimaPro $®$ are the most used LCA tools for sensitivity analysis. Manual sensitivity analysis can also be carried out in some cases, when results are presented in a range instead of precise values (Gnansounou et al., 2008a; Cherubini et al., 2009). The system input emission factors vary from one database to another. Each database has various inputs, based on which LCA calculates its carbon intensity in accordance with the methodological choices. Therefore, the obtained results for carbon intensities from GREET ${ }^{\circledR}$ model may be different from what achieved by Ecoinvent ${ }^{\circledR}$ database (Gnansounou et al., 2008a and 2009).

\section{Estimation of GHG savings and energy balances of biofuels}

Biofuels are often classified as first, second, and third generation biofuels (Table 1). First-generation biofuels utilize food crops as feedstock for biofuel production, while second-generation biofuels utilize non-food biomass. Third-generation biofuels use algae and microbes as fuel source materials (Singh et al., 2012). Various LCA based biofuel studies that have estimated the GHG emission savings and energy balances are grouped in Table 2. Following is the detail of GHG savings and energy balances of most prominent biofuel systems, relative to conventional fossil fuels.

Table 2.

Literature review on the estimation of energy and GHG balances of biofuels based on LCA studies.

\begin{tabular}{|c|c|c|c|c|}
\hline Feedstock & System adopted & Estimations & Year & References \\
\hline Maize, Switch grass & Various & Energy and GHG & 2006 & Farrell et al. (2008) \\
\hline $\begin{array}{l}\text { Rapeseed, Recycled vegetable oil, Wood chip } \\
\text { (residues, woodland management and short-rotation coppice), }\end{array}$ & $\mathrm{WtT}^{1}$ & Energy and GHG & 2003 & Elsayed et al. (2003) \\
\hline
\end{tabular}

Miscanthus, Straw, Ligno-cell, Beet, Wheat

Ethanol: Wheat, Beet, Straw, Wood waste, Sugar cane

Methanol: Wood waste, Farmed wood

Diesel: Rapeseed, Sunflower

WtT and $\mathrm{TtW}^{2} \quad$ Energy and GHG $2007 \quad$ Edwards et al. (2007)

Maize, Switchgrass

WtT

Palm oil

$\mathrm{WtW}^{3}$

Maize, Sugar cane, Soybean, Palm oil, Waste material

$\mathrm{WtW}$

Maize, Switchgrass

$\mathrm{WtW}$

Maize, Wheat, Cellulose

WtW

Imported soy oil $(40 \%) /$ domestic

Sunflower oil (10\%)/ imported Palm (25\%)/domestic and imported rapeseed WtW

$(25 \%)$

WtW Energy and GHG $2006 \quad$ Lechón et al. (2007)

Wheat straw

WtT and $\mathrm{TtW}$

Energy and GHG

2006

Veeraragha van and Riera-Palou (2006)

Sugarcane, Maize

$\mathrm{WtW}$

Energy and GHG

2005

de Oliveira et al. (2005)

Wheat, Barley

WtW

Energy and GHG

2005

Lechón et al. (2005)

Sugar cane

WtW

Biogas: Woody biomass, Beet, Lignocellulose, Rapeseed

WtT and TtW

Energy and GHG

2004

Macedo et al. (2004)

Wheat, Sunflower, Rapeseed

WtT

Energy and GHG 2002

Choudhury et al. (2002)

Energy and GHG $2002 \quad$ Ecobilan PwC (2002)

${ }^{1}$ WtT : Well to Tank

${ }^{2}$ WtW: Well to Wheel

${ }^{3}$ TtW: Tank to Wheel 


\subsection{Bioethanol}

Bioethanol is one of the most widely used biofuels in the world. Globally, bioethanol production grew from 17,000 to 65,614 million litres from 2006 to 2008, respectively (RFA, 2009). In 2015, global bioethanol production reached up to 25576 million gallon with a maximum share of $57 \%$ from the United States of America (USA) (RFA, 2016). In the USA, about 13.7 billion gallon of fuel ethanol were added to motor gasoline in 2015. This fuel ethanol accounted for about $10 \%$ of the total volume of motor gasoline consumed in the country (US-EIA, 2016). Moreover, it is estimated that bioethanol will provide 7\% of total global energy as a transportation fuel by 2030 (Escobar et al., 2009). Bioethanol is produced from starch and sugar crops such as cassava, wheat, barley, corn grain, or sugarcane (Kim and Dale, 2004; Nguyen et al., 2007; Macedo et al., 2008). The non-food biomass sources can also be used for producing bioethanol (Reijnders, 2008; Sassner et al., 2008; Najafi et al., 2009; Gonzalez-Garcia et al., 2010). The process of bioethanol production is similar to conventional brewing beer process; where starch crops are converted into sugars, then the sugars are fermented into ethanol, and finally the ethanol is distilled into the final product. Bioethanol is blended with gasoline at ratios ranging from 2 to $85 \%$ by volume in order to use in flexible fuel vehicles (FFV) (UNICA, 2009; Ansari and Verma, 2012). Moreover, $100 \%$ ethanol concentration could also be used in dedicated vehicles (Zhi Fu etal., 2003; Macedo et al., 2008; Hahn-Hägerdal et al., 2009; Gonzalez-Gracia et al., 2012).

An array of feedstocks including sugarcane, maize, sugar beet, cereal crops, cassava, potato, wheat, and cellulosic materials were studied for estimating their energy balance when producing bioethanol (Rosenberger et al., 2001; Kim and Dale, 2005; Malca and Freire, 2006; Renouf et al., 2008; Gracia et al., 2011; Papong and Malakul, 2010). Although bioethanol has a lower energy content than conventional gasoline, but its high-octane value results in higher compression ratios and efficient thermodynamic operation in internal-combustion engines (Nguyen et al., 2007). Energy balance investigation of bioethanol from sugarcane in Mexico showed an energy ratio of $4.8 \mathrm{GJ}_{\text {Ethanol }} / \mathrm{GJ}_{\text {Fossil. }}$. However, this value was lower in comparison with the Brazilian sugarcane-ethanol energy ratio of $8.4 \mathrm{GJ}_{\text {Ethanol }} \mathrm{GJ}_{\text {Fossil }}$ (Gracia et al., 2011). Sugarcane-bioethanol system has high yields of net energy and net potential of reducing GHG emissions than gasoline, as no energy is required to depolymerize carbohydrate into fermentable sugars (Macedo, 1998; Liska and Cassman, 2008). In a comparative study, Koga et al. (2013) reported an energy efficiency of 4.63 $\mathrm{MJ} \mathrm{L}^{-1}$ energy input in Kon-iku (potato type no. 38) and traditional practice potato (5.68 $\mathrm{MJ} \mathrm{L}^{-1}$ energy input) in northern Japan for bioethanol production. Nguyen et al. (2007) estimated energy efficiency of cassava-bioethanol and found similar results with corn-grain bioethanol. Liska and Cassman (2008) recalculated metrics reported in an LCA by Malca and Freire (2006) and estimated a net energy ratio (NER) of 1.9 for wheat-bioethanol system. In a different study, Walker et al. (2011) analysed 5 different crops such as miscanthus, willow, winter wheat, rape, and potato for their energy balances.

Gonzalez-Gracia et al. (2010) showed a slight decrease in GHG emissions when shifting from clean gasoline to E10 blends of ethanol regardless of the feedstock type, e.g., alfalfa leaves, Ethiopian mustard, poplar, flax fibres and linseed, hemp fibres and dust. The use of E85 blends seems to be more advantageous than E10 in terms of GHG emission savings. Moreover, Gonzalez-Gracia et al. (2010) suggested that up to $88 \%$ of total GHG emission savings can be achieved with lignocellulosic sources such as alfalfa stems. Increased GHG emission savings with high blend of ethanol such as E85 and E100 is because of increased $\mathrm{CO}_{2}$ sequestration during crop cultivation. However, improving the production of crops requires higher use of fertilizer, which in return causes increased emissions of $\mathrm{N}_{2} \mathrm{O}$.

GHG savings for bioethanol varies according to the choice of system boundary. Some studies used WtT analysis (Elsayed et al., 2003), while others have considered well to wheel (WtW) analysis (Gnansounou and Dauriat, 2004; Beer and Grant, 2007; Edwards et al., 2007). For instance, WtW analysis is used for calculating complete GHG emission savings of biofuel to a reference system. However, engine performance results for biofuels compared with conventional fuels may influence the final outcomes. Gracia et al. (2011) in their WtT analysis, compared the GHG emission savings of Mexican sugarcane-bioethanol system with a reference fossil fuel. The land-use changes reverted the scenario, especially when the rainforest was converted to sugarcane crop. The conversion of maize-biomass into electrical and thermal energy saved (6.3 \pm 0.56$) \mathrm{Mg} \mathrm{CO}_{2}$ eq ha ${ }^{-1}$ on average, whereas Miscanthus chips saved (22.3 \pm 0.13$) \mathrm{Mg} \mathrm{CO}_{2} \mathrm{eq} \mathrm{ha}^{-1} \mathrm{yr}^{-1}$ (Felten et al., 2013). A cross comparison of GHG savings and energy balances of bioethanol studies is presented in Table 3 .

\subsection{Biodiesel}

Various edible and non-edible crops such as soybean (Balan et al., 2009), oil palm (Yanez et al., 2009; Kamhara et al., 2010), rapeseed (Long et al., 2011; Gardy et al., 2014), Ethiopian mustard (Bouaid et al., 2005 and 2009), sunflower (Rashid and Anwar, 2008; Xin et al., 2009), desert date (Deshmukh and Bhuyar, 2009), castor (Scholz and Silva, 2008), Jatropha (Diwani et al., 2009; Sharma et al., 2012), Pongamia (Das et al., 2009; Kesari and Rangan, 2010), Azadirachta (Nabi et al., 2006) were used as feedstock for biodiesel production. According to Prasad e al. (2007a and b), biodiesel production second and third generation

Table 3.

Energy and GHG balance of bioethanol.

\begin{tabular}{|c|c|c|c|c|c|c|c|}
\hline Feedstock & System adopted & Reference system & Functional unit & Energy Balance & GHG Balance & Country & Reference \\
\hline Reed canary grass & Cradle to grave & Coal & $\mathrm{CO}_{2} \mathrm{e}-\mathrm{C}$ & - & $84 \%$ GHG saving & USA & Adler et al. (2007) \\
\hline Switchgrass & Cradle to grave & Coal & $\mathrm{CO}_{2} \mathrm{e}-\mathrm{C}$ & - & $114 \%$ GHG saving & USA & Adler et al. (2007) \\
\hline Hybrid poplar & Cradle to grave & Coal & $\mathrm{CO}_{2}$ eq-C & - & $117 \%$ GHG saving & USA & Adler et al. (2007) \\
\hline Corn-soybean & Cradle to grave & Coal & $\mathrm{CO}_{2}$ eq-C & - & $38-41 \%$ GHG saving & USA & Adler et al. (2007) \\
\hline Corn stover & $\begin{array}{l}\text { Energy product } \\
\text { to gate }\end{array}$ & $\begin{array}{l}\text { Gasoline, a hypothetical } \\
\text { case of pure ethanol }\end{array}$ & $\begin{array}{l}1 \mathrm{~km} \text { driving of } \\
\text { mid-size car }\end{array}$ & Positive & Reduction in GWP & The Netherlands & Luo et al. (2009) \\
\hline Switchgrass and corn stover & Cradle to wheel & $\begin{array}{l}\text { Low-sulfur reformulated } \\
\text { gasoline }\end{array}$ & $\mathrm{CO}_{2}$ eq $\mathrm{km}^{-1}$ & Positive & $\begin{array}{l}\text { up to } 70 \% \text { lower GHG } \\
\text { emissions }\end{array}$ & Canada & Spatari et al. (2005) \\
\hline $\begin{array}{l}\text { Household and Biodegradable } \\
\text { municipal waste }\end{array}$ & Cradle to grave & Gasoline & $\begin{array}{l}\text { MJ of fuel } \\
\text { equivalent }\end{array}$ & - & $\begin{array}{l}\text { Up to } 92.5 \% \text { GHG emission } \\
\text { saving }\end{array}$ & UK & $\begin{array}{l}\text { Stichnothe and } \\
\text { Azapagic (2009) }\end{array}$ \\
\hline Corn stover & Cradle to grave & Gasoline & $\mathrm{CO}_{2} \mathrm{~km}^{-1}$ & - & $\begin{array}{l}\text { Reduction of } 267 \mathrm{~g} \mathrm{CO}_{2} \\
\mathrm{~km}^{-1}\end{array}$ & USA & Sheehan et al. (2004) \\
\hline Blue-Green Algae & Cradle to Grave & Gasoline & $\mathrm{CO}_{2}$ eq $\mathrm{MJ}_{\mathrm{EtOH}}^{-1}$ & Positive & $\begin{array}{l}67 \% \text { and } 87 \% \text { reductions in } \\
\text { the carbon footprint }\end{array}$ & USA & Luo et al. (2010b) \\
\hline Switchgrass- Corn Stover & Cradle to Grave & $\begin{array}{l}\text { Low sulfur reformulated } \\
\text { gasoline }\end{array}$ & $\mathrm{CO}_{2}$ eq km${ }^{-1}$ & - & $\begin{array}{l}\text { Up to } 65 \% \\
\text { lower GHG emissions }\end{array}$ & Canada & Spatari et al. (2005) \\
\hline
\end{tabular}


biofuels pathways has led to promising results (Christi, 2007; Campbell, 2008). However, these pathways are not yet at a commercial scale due to higher production cost and challenges in process and conversion technologies compared with the first generation biodiesel (Khan et al., 2009). Chemical and biological catalysts such as alkali and acidic compounds and lipase are often used in biodiesel production (Kim et al., 2007).

Biodiesel production from soybean comprises soybean production, its transportation to the processing facility, separation of oil and meal and conversion into biodiesel through transesterification process, and finally the distribution of biodiesel (Sheehan et al., 1998). Usually, a multistage stage transesterification process is required to convert crop-oil into biodiesel that can be used in conventional diesel engines. In 2014, global production of biodiesel (most of which as FAME) reached up to 30 billion litres with a maximum share from the USA (16\%), followed by Brazil and Germany (both with $11 \%$ ), Indonesia (10\%), and Argentina (9.7\%). Europe accounted for $39 \%$ of global biodiesel production in 2014 (REN21, 2009). Global biodiesel production is expected to reach up to 39 billion litres by 2024 (OECD-FAO, 2015).

The NER and fossil energy ratio (FER) of biodiesel from soybean were reported higher than those of the corn grain-bioethanol system, while, it was reported to have a 23\% smaller net energy yield (NEY) (Hill et al., 2006). This means that soybean-biodiesel requires more land area to yield the same amount of NEY compared with corn grain-bioethanol (Liska and Cassman, 2008). Hill et al. (2006) reported NER of 1.9 for soybean-biodiesel. While, Sheehan et al. (1998), reported FER of 3.215 for soybean-biodiesel using TEAM (Ecobalance, Neuilly-sur-Seine, France) as modelling software. According to Sharma et al. (2012), soybean-biodiesel can generate more energy than what required to grow the crops and convert them into fuel. Such controversy in energy balance of soybean-biodiesel was triggered after a study by Pimentel and Patzek (2005) who reported less energy output from biodiesel in comparison with fossil fuel inputs. They further claimed that the soybean-biodiesel needed $27 \%$ more fossil energy than the actual energy of the produced biodiesel. Pradhan et al. (2008) explained this negative value of energy using Pimentel and Patzek model as an arithmetic error and stated that it occurred during calculations related to lime application. Pimentel and Patzek (2005) reported that only $19.3 \%$ of the total input energy goes to the soybean meal, however, in reality $82 \%$ of the soybean mass goes into meal. Similarly, they assigned 4,800 kg lime $\mathrm{ha}^{-1} \mathrm{yr}^{-1}$ for the average soybean crop, while lime is used for only acidic soil to correct $\mathrm{pH}$ once in several years. Pradhan et al. (2008) reanalysed Pimentel's model with 3 other different models, including Ahmed, GREET, and NREL and concluded that the discrepancy in the energy balance of soybean - biodiesel was due to variation in the allocated energy proportions to biodiesel and its meal coproduct.

Palm oil yield per hectare is significant in comparison with soybean oil marking palm oil-biodiesel the most competitive biofuel in terms of gross energy (Liska and Cassman, 2008). Kamhara et al. (2010) reported 3.5 NER for palm oil-biodiesel in Indonesia, while Yanez et al. (2009) and de Souza et al. (2010) reported 4.7 and 2.33 NER, respectively, in Brazil. Similarly, high energy balance was also observed in sunflower oil (Sheehan et al., 1998), canola oil (Fore et al., 2011), rapeseed oil (Janulis, 2004), and microalgal oil (Batan et al., 2010). Zhang et al. (2013) observed a high energy gain for biodiesel from microalgae. However, due to expensive commercial-scale facilities and climate sensitivity of microalgae, the production of microalgae for microalgae-biodiesel is still in the developmental phase. More interesting results were achieved in a study by Zhang et al. (2013) who reported higher energy gain of biodiesel from wastewater sludge while they could also resolve the energy consumption and waste sludge disposal problems.

Leguminous crops such as soybean require less nitrogen fertilizer during crop production, thus have a high potential for GHG emission savings. The cultivation of rapeseed for biodiesel led to GHG emission savings of $3.2 \pm 0.38 \mathrm{Mg} \mathrm{CO}_{2}$ eq. ha ${ }^{-1}$ (Felten et al., 2013). GHG emission savings from the rapeseed-biodiesel ranged from 20 to $80 \%$ with an average value of $40-60 \%$ in comparison with conventional fuel (Menichetti and Otto, 2009). It should be noted that although palm oilbiodiesel is associated with the most promising energy (Liska and Cassman, 2008) and GHG emission savings (Beer et al., 2007; Zah et al., 2007), land-use changes adversely influence the results. Beer et al. (2007) explained that if rainforest and peat forest are converted into crop land for palm oil production, the results of GHG emission savings will revert to negative value ranging from 800 to $2000 \%$, respectively. A WtW analysis showed $1.1 \mathrm{~kg} \mathrm{CO}_{2}$ eq. for a $1 \mathrm{~km}$ travelling distance with a reference fossil fuel while rapeseed-biodiesel led to $0.48 \mathrm{~kg} \mathrm{CO}_{2}$ eq. for a similar distance with a total GHG emission saving of $56 \%$ (Finco et al., 2012). However, the study did not include land-use changes that can further reduce GHG emission savings. A study conducted by Finco et al. (2012) for rapeseed-biodiesel showed that agriculture phase was the major contributor to GHG emission $(68 \%)$ followed by transesterification process (18\%) and solvent extraction (8\%). Pehnelt and Vietze (2013) also analysed various similar scenarios. They indicated that the GHG emission savings from palm oil-biodiesel ranged from 37.1 to $85 \%$. The GHG savings and energy balances of biodiesel obtained from different sources are shown in Table 4.

Table 4.

Energy and GHG balance of biodiesel.

\begin{tabular}{|c|c|c|c|c|c|c|c|}
\hline Feedstock & System adopted & Reference system & Functional unit & Energy Balance & GHG Balance & Country & Reference \\
\hline Microalgae & Cradle to grave & Fossil diesel & $\begin{array}{l}\mathrm{Kg} \mathrm{CO}_{2} \text { eq } \text { ton }^{-1} \\
\text { biodiesel }\end{array}$ & $\begin{array}{l}\text { Positive in raceway pond } \\
\text { and negative in air-lift } \\
\text { tubular bioreactors }\end{array}$ & About $80 \%$ lower GWP & UK & Stephenson et al. (2010) \\
\hline Microalgae & Well to pump & Fossil diesel & $\begin{array}{l}\mathrm{Kg} \mathrm{CO}_{2}(1000 \mathrm{MJ} \\
\text { Energy })^{-1}\end{array}$ & - & $\begin{array}{l}\text { Positive } \mathrm{CO}_{2} \text { emissions } \\
\text { for the centrifuge process } \\
\text { while negative values for } \\
\text { the filter press process }\end{array}$ & USA & Sander and Murthy (2010) \\
\hline Rapeseed & Cradle to grave & Conventional gasoline & $1 \mathrm{PKM}$ & - & $\begin{array}{l}\text { Reduced green house gas } \\
\text { emission }\end{array}$ & Argentina & Emmenegger et al. (2011) \\
\hline $\begin{array}{l}\text { Microalgae } \\
\text { wastewater sludge }\end{array}$ & Cradle to grave & - & $\begin{array}{l}\text { GJ ton }{ }^{-1} \text { biodiesel } \\
\text { produced }\end{array}$ & Positive & $\begin{array}{l}\text { Sequestered carbon, } \\
\text { reduction in GHG emission }\end{array}$ & USA & Zhang et al. (2013) \\
\hline Rapeseed & Field to wheel & Conventional diesel & $1 \mathrm{~km}$ traveled by bus & - & $56 \%$ GHG savings & Italy & Finco et al. (2012) \\
\hline Pongamia pinnata & Field to wheel & Diesel & $\begin{array}{l}1 \text { MJ energy available } \\
\text { in Pongamia }\end{array}$ & - & $\begin{array}{l}1.5 \text { ton }+ \text { additional } 1 \text { ton } \\
\mathrm{CO}_{2} \text { sequestration potential } \\
\text { by } 1 \text { hectare Pongamia } \\
\text { pinnata }\end{array}$ & India & Chandrashekar et al. (2012) \\
\hline Jatropha & Well to Tank & Fossil Diesel & $1 \mathrm{MJ}$ of JME & - & $72 \%$ GHG savings & $\begin{array}{l}\text { Ivory Coast } \\
\text { and Mali }\end{array}$ & Ndong et al. (2009) \\
\hline Microalgae & Cradle to Grave & $\begin{array}{l}\text { first generation } \\
\text { biodiesel and oil diesel }\end{array}$ & $\begin{array}{l}1 \mathrm{MJ} \text { of fuel in diesel } \\
\text { engine }\end{array}$ & - & $\begin{array}{l}\text { Significantly decreased } \\
\text { environmental impacts }\end{array}$ & France & Lardon et al. (2009) \\
\hline
\end{tabular}




\subsection{Pure plant oil (PPO)}

Similar to biodiesel, pure plant oil (PPO) is also derived from lipids. Primary process steps such as feedstock production and oil extraction are also similar to those of biodiesel production. However, final production of PPO and its purification procedures are additional steps. Although the name of PPO refers to original vegetable-oil, but it also includes waste oil and oil from animal fats. PPO can be used in diesel engines, but due to its relatively high viscosity (12 times higher than fossil diesel) (WWI, 2006) and combustion properties (Paul and Kemnitz, 2006), engines should be modified and refitted. For PPO, no study has been conducted so far in order to investigate the energy balance and GHG emission savings. The energy consumed for transesterification of biodiesel can be saved in case of PPO while the absence of co-products as is the case for biodiesel, i.e., glycerol, can further save GHG emissions (Dreier and Tzscheutschler, 2001; Quirin et al., 2004).

\subsection{Biomass to liquid (BtL) biofuels}

BtL biofuels are produced by various techniques (Sawayama et al., 1999; Ledford, 2006; Jungbluth et al., 2008; Bensaid et al., 2012). The FischerTropsch (F-T) thermochemical synthesis can utilize a wide range of biomass sources to produce liquid biofuels. F-T synthesis using biomass has been successfully examined at pilot-plant scale and further development for biofuels of high quality is underway (Huber et al., 2006). One such F-T facility is located in Germany (Ledford, 2006). A full life cycle study conducted by Jungbluth et al. (2008), concluded that BtL biofuels from agricultural biomass, particularly short rotation crop did not show a significant reduction in GHG emissions and did not produce sufficient energy, while biomass used from forestry could increase both GHG emission savings and energy balance.

Bensaid et al. (2012) conducted a study on converting biomass wastes into valuable liquid biofuel by choosing a direct liquefaction technology. They reported process power consumption of $0.258 \mathrm{kWh} / \mathrm{kg}$ oil corresponding to an output/input energy ratio of 35.8. Moreover, they manage to achieve an output/input energy ratio of 9.7 , even without power generation. Oil recovered by thermochemical liquefaction from microalgae such as Botryococcus braunii showed 1.6 times more heating value (HHV) $(45.9 \mathrm{MJ}$ $\left.\mathrm{kg} \mathrm{yr}^{-1}\right)$ than coal (28 MJ kg yr$\left.{ }^{-1}\right)$ along with a high energy balance (Sawayama et al., 1999). They also reported high energy balance for liquefaction of sewage as no net energy is used for sewage production. Similarly, Nzihou et al. (2012) concluded that significant benefits in energy and GHG balances could be gained by using solar energy as external heating source for the standard gasification process.

Agrawal et al. (2009) proposed an innovative way of producing biofuels by combining biomass and hydrogen from a carbon-free energy source. The produced biofuels had three times more yield per unit mass of biomass in comparison with the conventional gasification F-T process. The energy contents of the biomass and hydrogen fed into the conversion plant were higher for the hybrid hydrogen-carbon process. It should be noted that hydrogen-cars are one of the examples that can achieve the carbon efficiency of nearly $100 \%$ in comparison with $37 \%$ for the conventional process. Moreover, the use of second generation biofuels can result in a greater $\mathrm{CO}_{2}$ reduction per biomass unit used (Martinsen et al., 2010). Therefore, changes in biomass source can further improve the potential of GHG emission savings. On the contrary, Monti et al. (2009) found 50 to $60 \%$ less impact on GHG emission savings by changing conventional crops to more efficient energy crops.

Life cycle study of BtL biofuels carried out by van Vliet et al. (2009) concluded that GHG emissions from F-T process depend on the efficiency of conversion plants, biomass intermediates, and the use of feedstock. Coal-to-liquid chains without carbon capture and storage were reported to increase transportation-related GHG emissions. While, gas-to-liquid with carbon capture and storage was found to reduce GHG emissions by around 5\% in comparison with fossil diesel. Moreover, the net emissions from BtL can be smaller and negative through the application of carbon capture and storage. Therefore, a net climate neutral biofuel can be made by using around $50 \% \mathrm{BtL}$ with carbon capture and storage and blending it with other fuels. For instance, if biomass gasification and carbon sequestration are operated at industrial scale, and the feedstock is obtained in a sustainable way, the resultant biofuel will be climate neutral. GHG savings and energy balances of BtL biofuels are shown is Table 5 .

\subsection{Biomethane}

A range of feedstocks such as organic fraction of municipal solid waste (OFMSW), sludge, slaughterhouse waste, biofuel residues, industrial, agricultural and forestry residues, and energy crops can be used in anaerobic digestion (AD) (Prasad et al., 2007; Smith et al., 2009; Sadaf et al., 2016; Tahir et al., 2015). Biogas produced through AD is purified and

Table 5.

Energy and GHG balance of BtL.

\begin{tabular}{|c|c|c|c|c|c|c|c|}
\hline Feedstock & System adopted & Reference system & Functional unit & Energy Balance & GHG Balance & Country & Reference \\
\hline $\begin{array}{l}\text { Rapeseed } \\
\text { Oil palm } \\
\text { Jatropha }\end{array}$ & Cradle to grave & Conventional diesel & $317 \mathrm{GJ}$ & - & GWP reduced by about half & USA & Clarens et al. (2010) \\
\hline Micro algae & Cradle to grave & Coal thermal plant & - & Positive & $\begin{array}{l}\text { Reduction in GHG } \\
\text { emissions }\end{array}$ & Japan & Sawayama et al. (1999) \\
\hline $\begin{array}{l}\text { Microalgae } \\
\text { Canola } \\
\text { Switchgrass } \\
\text { Corn }\end{array}$ & Cradle to gate & Comparison & $317 \mathrm{GJ}$ & Positive & GHG savings & USA & Clarens et al. (2010) \\
\hline $\begin{array}{l}\text { Sugar cane } \\
\text { Sugar crops } \\
\text { Jatropha } \\
\text { Algae } \\
\text { Palm oil } \\
\text { Short rotation woody } \\
\text { crops } \\
\text { Forestry wood } \\
\text { Wood residues } \\
\text { Agricultural residues } \\
\text { Used cooking oil } \\
\text { Waste }\end{array}$ & Cradle to grave & fossil reference system & Variable & Positive & $\begin{array}{l}\text { Reduction in GHG } \\
\text { emissions }\end{array}$ & Norway & Cherubini and Strømman (2011) \\
\hline
\end{tabular}


upgraded to enriched biomethane (up to $97 \% \mathrm{CH}_{4}$ ) that can be blended with or used as an alternative fuel in natural gas vehicles or as a source of thermal energy (Murphy et al., 2013). For efficient distribution of produced biomethane, the existing network of natural gas grid can be utilized with endapplications of electricity, thermal, and transportation energy generation (Korres et al., 2010). The biomethane generated from grass or grass silage is considered sustainable biofuel by the EU Renewable Energy Directive (ECDirective, 2009). However, to make grass-biomethane commercially available, an efficient vehicle and carbon sequestration with up to $60 \% \mathrm{GHG}$ emission savings is required (Singh et al., 2011).

Dressler et al. (2012) reported a low net energy demand of -0.274 to 0.175 $\mathrm{kWh} / \mathrm{kWh}_{\mathrm{el}}$ at Celle region of Germany because of using combined heat and power (CHP) unit in the region. Thyø and Wenzel (2007) concluded that biogas produced from manure has high fossil fuel savings in comparison with conventional manure storage and manure soil application. The GHG emissions correlated with the cultivation of energy maize ranged from 45.4 to $57.7 \mathrm{~kg} \mathrm{CO}_{2}$ eq. $\mathrm{t}^{-1}$ of fresh maize. While, GHG emissions range from 0.179 to $0.058 \mathrm{~kg} \mathrm{CO}_{2}$ eq. $\mathrm{kWhe}^{-1}$, when biogas was produced and used from maize (Dressler et al., 2012). They showed more efficiency in term of GHG emission savings in comparison with the study by Vogt (2008a), because part of the mineral fertilizers was substituted by digester output (i.e. digestate). However, the choice of fermenter was not considered by Dressler et al, (2012), which could have further manipulated the GHG emission savings. Vogt (2008b) also showed the influence of open and closed fermenters on GHG emission savings. The direct emissions from the fermenters can account for 25 to $75 \%$ of the overall GHG emissions. Depending on the level of carbon sequestration 75 to $150 \%$ GHG emission savings were achieved for grass biomethane in comparison to fossil fuel (Korres et al., 2010). Singh and Murphy (2009) reported 82\% GHG emission savings for cattle slurrybiomethane in comparison to diesel, while savings of 21 to $53 \%$ were achieved for grass-biomethane in comparison to diesel. The GHG savings and energy balances of biomethane studies are shown is Table 6 .

\subsection{Biohydrogen}

Biohydrogen is a promising candidate for future energy supplies due to being renewable in nature with no GHG emissions during combustion, as well as easy conversion into electricity through fuel cells (Hallenbeck and Benemann, 2002). It has the largest energy contents per weight in comparison with other fuels. It can be produced by different techniques such as water splitting, coal gasification, and natural gas reforming (Levin et al., 2004). However, these methods for biohydrogen production need high energy inputs using non-renewable resources (Levin et al., 2004). Biological production of hydrogen using bioelectrochemical systems such as microbial electrolysis cells (MEC) can solve this problem by using microorganisms for converting biomass into hydrogen gas $\left(\mathrm{H}_{2}\right)$ (Das anc Veziroglu, 2001; Hallenbeck and Benemann, 2002). Although biohydrogen production rates in MECs are still not high enough, more research is underway to optimize the performance of MECs (Zhu and Beland, 2006). Moreover, Rathore and Singh (2013) discussed in detail the potential role of microalgae for biohydrogen production.

Cheng and Logan (2007) conducted a study on exoelectrogenic bacteria in specially designed reactors to produce $\mathrm{H}_{2}$ from biodegradable organic matters through the electrohydrogenesis process. They observed the overall energy efficiency of $288 \%$ for the process that was based on the electricity applied. While, an efficiency of $82 \%$ was achieved, when the combustion heat of acetic acid was included in the energy balance, at a biohydrogen production rate of $1.1 \mathrm{~m}^{3} \mathrm{~d}^{-1}$ per each cubic meter of the reactor. A high yield of biohydrogen was also observed by using glucose, several volatile acids such as acetic, butyric, lactic, propionic, and valeric, and cellulose at maximum stoichiometric yields of 54-91\%. The achieved energy efficiencies ranged from 64 to 82\%. Djomo and Blumberga (2011) reported $1.08,1.14$, and 1.17 energy ratios for wheat straw, sweet sorghum stalk, and steam potato peels, respectively, without considering the co-products such as protein residues. The energy efficiency was further enhanced by $23-128 \%$, when the co-products were taken into account.

Biohydrogen is considered a clean fuel if does not produce $\mathrm{CO}_{2}$ during combustion. By using biohydrogen instead of natural gas, heavy fuel oil, and coal to produce electricity, 33, 39.5, and $39 \% \mathrm{CO}_{2}$ emissions could be avoided, respectively (Ranagnoli et al., 2011). Djomo and Blumberga (2011) reported 55.53, 54.30, and 51.84\% GHG emission savings when steam potato peels, sweet sorghum stalk, and wheat strew were used for biohydrogen production, respectively. However, a negative value (3.93\%)

Table 6.

Energy and GHG balance of biomethane.

\begin{tabular}{|c|c|c|c|c|c|c|c|}
\hline Feedstock & System adopted & Reference system & Functional unit & Energy Balance & GHG Balance & Country & Reference \\
\hline \multirow[t]{2}{*}{ Grass } & Cradle to Grave & Fossil diesel & & Positive & $54-75 \%$ GHG savings & Ireland & Korres et al. (2010) \\
\hline & & & $\mathrm{CO}_{2}$ eq KWhe ${ }^{-1}$ & & & & \\
\hline \multirow[t]{2}{*}{ Maize } & Cradle to grave & Fossil fuel & & & $\begin{array}{l}\text { GHG emission } 0.179 \text { to } \\
0.058 \mathrm{~kg} \mathrm{CO}_{2} \text { eq. } \mathrm{KWhe}^{-1}\end{array}$ & Germany & Dressler et al. (2012) \\
\hline & & & $\mathrm{CO}_{2}$ eq KWhe ${ }^{-1}$ & & & & \\
\hline Grass & Cradle to grave & Fossil diesel & & Positive & Up to $85 \%$ GHG savings & Ireland & Singh et al. (2010a) \\
\hline Bagasse & Cradle to gate & $\begin{array}{l}\text { Landfilling with utilization } \\
\text { of landfilled gas }\end{array}$ & $\begin{array}{l}\text { MWh of electricity ton }{ }^{-1} \text { of } \\
\text { pulp produced }\end{array}$ & - & $\begin{array}{l}\text { Reduction in GHG } \\
\text { emissions }\end{array}$ & Thailand & $\begin{array}{l}\text { Kiatkittipong et al. } \\
(2009)\end{array}$ \\
\hline $\begin{array}{l}\text { Maize silage } \\
\text { Manure }\end{array}$ & Cradle to Grave & Gasoline & $\begin{array}{l}\text { KM Transport } \\
\text { GJ Heat } \\
\text { GJ Power }\end{array}$ & Positive & $\begin{array}{l}\text { Reduction in GHG } \\
\text { emissions }\end{array}$ & Germany & Thyø and Wenzel (2007) \\
\hline Biowaste & Cradle to Gate & Incineration & $\mathrm{Km}^{2}$ area $\operatorname{ton}^{-1}$ biowaste & - & $\begin{array}{l}\text { Reduction in GHG } \\
\text { emissions }\end{array}$ & Spain & Güereca et al. (2006) \\
\hline $\begin{array}{l}\text { Silage maize } \\
\text { Silage grass } \\
\text { Silage rye } \\
\text { Forage beet }\end{array}$ & Cradle to Grave & Grid electricity & $\begin{array}{l}1 \text { Terajoule electricity fed } \\
\text { into public electricity } \\
\text { system }\end{array}$ & - & $\begin{array}{l}\text { Reduction in GHG } \\
\text { emissions }\end{array}$ & Germany & Hartmann (2006) \\
\hline Energy crops & Cradle to Grave & Natural gas & $\begin{array}{l}1 \mathrm{MJ} \text { injected into natural } \\
\text { gas grid }\end{array}$ & Positive & $\begin{array}{l}\text { Reduction in GHG } \\
\text { emissions }\end{array}$ & Luxembourg & Jury et al. (2010) \\
\hline
\end{tabular}

Please cite this article as: Rathore D., Nizami A.S., Singh A., Pant D. Key issues in estimating energy and greenhouse gas savings of biofuels: challenges and perspectives. Biofuel Research Journal 10 (2016) 380-393. DOI: 10.18331/BRJ2016.3.2.3 
Table 7.

Energy and GHG balance of biohydrogen.

\begin{tabular}{|c|c|c|c|c|c|c|c|}
\hline Feedstock & System adopted & Reference system & Functional Unit & Energy Balance & GHG Balance & Country & Reference \\
\hline Potato steam peels & Cradle to Grave & Defined & $1 \mathrm{~kg} \mathrm{H}_{2} \mathrm{Kg}^{-1}$ Potato peel & - & $\begin{array}{l}\text { Reduction of GHG } \\
\text { emissions }\end{array}$ & USA & Djomo et al. (2008) \\
\hline $\begin{array}{l}\text { Green algae } \\
\text { Cyanobacteria } \\
\text { Potatoes peels }\end{array}$ & Cradle to Well & Not defined & $\begin{array}{l}\text { MW yr }{ }^{-1} \\
\text { GJ yr }\end{array}$ & - & $\begin{array}{l}\text { Reduction of GHG } \\
\text { emissions }\end{array}$ & Latvia & Romagnoli et al. (2011) \\
\hline Sugarcane juice & Cradle to Grave & Electricity & $\begin{array}{l}\mathrm{Kg} \mathrm{CO} \\
\mathrm{MJ}\end{array}$ & Positive & $\begin{array}{l}57-73 \% \text { reduction of } \\
\text { GHGs }\end{array}$ & India & Manish and Banerjee (2008) \\
\hline Potato peels & Well to Wheel & $\begin{array}{l}\text { Conventional fossil } \\
\text { diesel and gasoline }\end{array}$ & $\mathrm{gCO}_{2} \mathrm{MJH}_{2}^{-1}$ & $\begin{array}{l}\text { Positive ( } 45-52 \% \text { reduction } \\
\text { of energy consumption) }\end{array}$ & $\begin{array}{l}65-69 \% \text { reduction of } \\
\mathrm{CO}_{2} \text { emissions }\end{array}$ & Portugal & Ferreira et al. (2011) \\
\hline Biomass gasification & Cradle to Grave & Diesel & $\begin{array}{l}1 \mathrm{MJ} \mathrm{s}^{-1} \text { hydrogen } \\
\text { production }\end{array}$ & Positive & $\begin{array}{l}\text { Reduction of GHG } \\
\text { emissions }\end{array}$ & Turkey & Kalinci et al. (2012) \\
\hline Food waste and wheat feed & Cradle to Grave & Diesel & $1 \mathrm{~km}$ of Transportation & Positive & $\begin{array}{l}\text { Reduction of GHG } \\
\text { emissions }\end{array}$ & UK & Patterson et al. (2013) \\
\hline Microalgae biomass & Cradle to Grave & Electricity & $\begin{array}{l}\mathrm{g}\left(1 \mathrm{MJ} \text { of } \mathrm{H}_{2}\right. \\
\text { produced })^{-1}\end{array}$ & - & $\begin{array}{l}\text { Reduction of GHG } \\
\text { emissions }\end{array}$ & Portugal & Ferreira et al. (2013) \\
\hline
\end{tabular}

was observed for biohydrogen from steam methane. Several other examples for biohydrogen production with their respective GHG savings and energy balances are presented in Table 7 .

\section{Challenges and perspectives in GHG savings and energy balances of biofuels}

The environmental performance of biofuels based on their GHG savings and energy balances depend on a wide range of factors such as feedstock types, conversion technologies, issues related to land-use and land-use changes along with substituted products like electricity, transportation fuel, and animal feed (Menichetti and Otto, 2009). The distribution of impacts for estimating GHG savings and energy balances vary from study to study (Table 3 ). As long as the GHG emissions are concerned, agricultural activities share a major role due to release of nitrogen gases (i.e., $\mathrm{N}_{2} \mathrm{O}$, NOx) and $\mathrm{SOx}$ with the use of fertilizers. Moreover, they are also responsible for acidification and eutrophication. The treatment of co-products and the allocation of impacts for co-products also change the LCA results significantly (Box 1).

Energy estimations are influenced significantly by technology conversion pathways as well. Moreover, the type of energy input in the form of heat and power from coal, natural gas, petroleum or bagasse, and energy quantity change the results of LCA studies (Wang et al., 2007). For example, when coal is used as a fuel in the corn-ethanol system, the GHG emissions are three times higher than gasoline. However, by using biomass feedstock like wood chips as an energy source, the GHG emission savings were surpassed by $50 \%$. Besides agricultural activities, the fate of co-products, allocation of impacts, life cycle inventory databases and life cycle impact assessment methods could result in different LCA outcomes (Box 1). Assumptions on vehicle performance and biofuel transportation distance could also influence the LCA results (Menichetti and Otto, 2009).

Based on the results of a survey, Kim and Dale (2009) presented regional differences in GHG emissions from corn-ethanol and soybean oil production in 40 different counties in the USA. They observed that with the selection of feedstock material for biofuel production, the fertilizer requirement changes, which is another major source of GHG emissions. Dressler et al. (2012) also observed local and regional variations in GHG emissions at three different districts of Germany. They reported 50-56\% GHG emissions from the cultivation stage with a minimum emission at the district of Gottingen, because of lower demand of fertilizers, pesticides, and fuel. According to Kim and Dale (2009), $\mathrm{N}_{2} \mathrm{O}$ emissions from the soil and nitrogen fertilizers during energy crops cultivation resulted in the highest GHG emissions, accounting for 13 to $57 \%$ of all GHG emissions.

Brazil and Indonesia showed a large percentage of GHG emissions from land-use changes that account for $61 \%$ of the world $\mathrm{CO}_{2}$ emissions originated from land-use changes (Le Quéré et al., 2009). This means, a biofuel crop with higher-energy productivity may have less land-use change emissions per MJ than a less productive biofuel crop, even from the same field. Therefore, it is possible that a productive biofuel crop can be combined with the optimum management techniques to achieve the EU's target of 35\% minimum GHG emission savings for biofuels (Lange, 2010).

The assumptions and data used in most of the LCA based studies on biofuels are taken from the Europe and the USA based technology pathways. Therefore, there is a strong need to focus on the Asian and South American countries as well (Box 2). This will increase the representativeness of LCA studies around the globe, including the developing countries. The non-GHG environmental impact factors, including acidification, eutrophication, human health, and toxicity should be considered in future LCA studies. LCA results should be extended to the local and regional needs and conditions by considering other environmental assessment methods. Moreover, LCA results should also take direct land-use change impacts into consideration (Box 2).

It is worth quoting that LCA studies do not assess the large-scale development of any technology or product, therefore, the other assessment tools such as agro-economic market models should also be used (Box 1). Moreover, there is a strong need to reach national and international consensus on the use and execution of biofuels-related LCAs by considering the GHG emission savings goals. This will lead to a set of approaches and assumptions on significant indicators such as technology status, land-use carbon stock, $\mathrm{N}_{2} \mathrm{O}$ emissions, and impact allocation for co-products (Menichetti and Otto, 2009).

\section{Conclusion}

- A wide range of results in terms of net energy balances and net GHG emission savings has been obtained from various biofuel production systems and their biomass sources. The factors causing such variations in results are different feedstock types, conversion technologies, land-use and land-use changes, replaced products like electricity, transportation fuel, and animal feed. 
- The net GHG emission savings were expressed in terms of $\mathrm{CO}_{2}$ equivalent in almost all of the presented cases. The agricultural activities, selection of feedstock, and treatment of co-products and the allocation of impacts for co-products are the major contributors to GHG emissions.

- For biomethane, bioethanol, and biodiesel production systems, the choice of reactor is one of the main parameters leading to significant variations in GHG emission savings.

- Land-use and land-use changes may sometimes result in an overestimation of a biofuel efficiency. Environmental and social sustainability of biofuels production are the key factors for the development of biofuel support policies.

- Higher GHG emission savings and energy balances with biofuels can be achieved, when biomass yields are high, particularly when ecologically sustainable biomass or non-food biomass are converted into biofuel and used efficiently.

\section{Box 1.}

Key issues in LCA bases studies on biofuels (Cherubini and Strømman, 2011. IPCC, 2011; Cherubini et al., 2009; Menichetti and Otto, 2009).

- LCA studies are being carried out continuously, but their number is still small in comparison with other processes.

- Most of the LCA based studies were carried out by following the US or European conditions and adopting their agriculture processes and conversion technologies.

- Most common LCA based studies have referred to the firstgeneration biofuels, while a few studies investigated the secondgeneration biofuels.

- Most of the researchers have considered the traditional feedstock such as rapeseed wheat, sugar corn, corn, etc. for LCA studies. However, a few have tried to assess the LCA of recent biofuel crops such as sweet sorghum and Jatropha.

- In most of the LCA based studies, emphasis has been placed on the energy consumption either only from non-renewable sources or total energy sources. However, a few studies included all the other potential impacts of the process such as eutrophication, acidification, toxicity potential, and ozone depletion. Moreover, water impacts have been included in very limited number of studies.

- There is no LCA based study accounting the impacts on biodiversity. The methods for development of biodiversity indicators are still under discussion.

- Impacts on direct land-use and land-use changes due to crop production have less been studied. Limited studies described alternative land-use as reference system and calculated the carbon stock. Moreover, potential impacts on land due to its indirect use for high bioenergy production demand are not measured.

- The complexity level of LCA studies is quite high due to variable nature of assumption and hypothesis, emission factor, yield, heating value, and other background methodological choices. However, limited studies included a quality data review required for LCA in accordance with ISO standards.

- Variations have been observed in managing the co-products, and impact allocation methods.

- Social issues are sometime ignored during the LCA process. This shows that the pure focus is on the environment aspects of the LCA process.

- Different databases are used for LCA studies. However, old databases have been used more frequently, which could affect the results quality regardless of the quality of primary data collection.
Box 2.

Future directions for LCA based studies on biofuel (Cherubini and Strømman, 2011; IPCC, 2011; Cherubini et al., 2009; Menichetti and Otto, 2009).

- The future biofuel systems have to satisfy all aspects of environmental, economica, and social factors, especially the impacts on biodiversity, water resources, human health, and toxicity, and food security.

- The assumptions and data used in LCA based studies on biofuels should be based on regions rather than European and North American conditions as well, such as like Brazil, China, and Southeast Asia.

- More research and development is required to commercialize the second-generation biofuels that are made from non-food biomass sources to solve the food, feed, and fibre production issues. There is a possibility that such LCA studies will be based on uncertainties, as there is no such biofuel system commercially established yet. Therefore, uncertainties and parameter sensitivities should be handled carefully. arametric type LCA will be useful tool in this regard.

- The future LCA studies need to consider the integrated multifuel and multi-product systems like biorefineries.

- There is also a need to properly define the system boundaries in connection with land-use and land-use change.

- The GHG emission savings can be increased for a biofuel based on increased carbon sequestration when using perennial grasses established in set-aside and annual crop land.

- LCA findings of biofuels from dedicated crops should be expressed in per hectare basis.

- LCA results of biofuels from biomass residues should be expressed in per unit output basis.

- For transportation biofuels, the LCA results should be expressed in per km basis.

- There is a need to solve the issues related to liquid biofuels that require more fossil-based energy than the generation of heat and electricity from biomass.

- The emphasis should be given to the residues and organic wastes that can be employed for biofuels production since they have been shown to lead to maximum GHG emission savings due to direct reduction of emissions related to waste disposal.

- High GHG emission savings and energy balances can be achieved if agricultural co-products and process residues are used for biofuel production. However, the effect of residues removal from the soil and the GHG implications should also be considered.

- Higher GHG emission savings can be achieved if biomass is utilized in making value-added products.

\section{References}

[1] Adler, P.R., Grosso, S.J.D., Parton, W.J., 2007. Life-cycle assessment of net greenhouse-gas flux for bioenergy cropping systems. Ecol. Appl. 17(3), 675-691.

[2] Agrawal, R., Singh, N.R., Ribeiro, F.H., Delgass, W.N., Perkis, D.F., Tynerb, W.E., 2009. Synergy in the hybrid thermochemicalbiological processes for liquid fuel production. Comput. Chem. Eng. 33(12), 2012-2017.

[3] Ansari, F.T., Verma, A.P., 2012. Experimental determination of suitable ethanol-gasoline blend for spark ignition engine. Int. J. Eng. 1(5), 10 pages

[4] Atilgan, B., Azapagic, A., 2015. Life cycle environmental impacts of electricity from fossil fuels in Turkey. J. Cleaner Prod. 106, 555564 
[5] Arvidsson, R., Persson, S., Froling, M., Svanstromb, M., 2011. Life cycle assessment of hydrotreated vegetable oil from rape, oil palm, and Jatropha. J. Cleaner Prod. 19, 129-137.

[6] Balan, V., Rogers, C.A., Chundawat, S.P.S., Sousa, L.D.C., Slininger, P.J., Gupta, R., Dale, B.E., 2009. Conversion of extracted oil cake fibers into bioethanol including DDGS, canola, sunflower, sesame, soy, and peanut for integrated biodiesel processing. J. Am. Oil Chem. Soc. 86(2), 157-165.

[7] Batan, L., Quinn, J., Willson, B., Bradley, T., 2010. Net energy and greenhouse gas emission evaluation of biodiesel derived from microalgae. Environ. Sci. Technol. 44(20), 7975-7980.

[8] Beer, T., Grant, T., 2007. Life-cycle analysis of emissions from fuel ethanol and blends in Australian heavy and light vehicles. J. Cleaner Prod. 15 (8-9), 833-837.

[9] Beer, T., Grant, T., Campbell, P.K., 2007. The greenhouse and air quality emissions of biodiesel blends in Australia. CSIRO Mar. Atmos. Res. (CMAR), Australia.

[10] Bensaid, S., Conti, R., Fino, D., 2012. Direct liquefaction of lignocellulosic residues for liquid fuel production. Fuel. 94, 324-332.

[11] Bouaid, A., Diaz, Y., Martinez, M., Aracil, J., 2005. Pilot plant studies of biodiesel production using Brassica carinata as raw material. Catal. Today. 106(1-4), 193-196.

[12] Bouaid, A., Martinez, M., Aracil, J., 2009. Production of biodiesel from bioethanol and Brassica carinata oil: oxidation stability study. Bioresour. Technol. 100(7), 2234-2239.

[13] Campbell, M.N., 2008. Biodiesel: algae as a renewable source for liquid fuel. Guelph. Eng. J. 1, 2-7

[14] Chandrashekar, L.A., Mahesh, N.S., Gowda, B., Hall, W., 2012. Life cycle assessment of biodiesel production from pongamia oil in rural Karnataka. Agric. Eng. Int.: CIGR J. 14(3), 67-77.

[15] Cheng, S., Logan, B.E., 2007. Sustainable and efficient biohydrogen production via electrohydrogenesis. PNAS. 104(47), 18871-18873.

[16] Cherubini, F., Strømman, A.H., 2011. Life cycle assessment of bioenergy systems: State of the art and future challenges. Bioresour. Technol. 102(2), 437-451

[17] Cherubini, F., Bird, N.D., Cowie, A., Jungmeier, G., Schlamadinger, B., Woess-Gallasch, S., 2009. Energy-and greenhouse gas-based LCA of biofuel and bioenergy systems: key issues, ranges and recommendations. Resour. Conserv. Recycl. 53, 434-447.

[18] Choudhury, R., Weber, T., Schindler, J., Weindorf, W., Wurster, R., 2002. GM well to wheel analysis of energy use and greenhouse gas emissions of advanced fuel/ vehicle systems- a European study. Ottobrunn, Germany.

[19] Christi, Y., 2007. Biodiesel from microalgae. Biotechnol. Adv. 25(3), 294-306.

[20] Clarens, A.F., Resurreccion, E.P., White, M.A., Colosi, L.M., 2010. Environmental life cycle comparison of algae to other bioenergy feedstocks. Environ. Sci. Technol. 44(5), 1813-1819.

[21] Das, D., Veziroglu, T.N., 2001. Hydrogen production by biological processes: a survey of literature. Int. J. Hydrogen Energy. 26(1), 13-28.

[22] Das, L.M., Bora, D.K., Pradhan, S., Naik, M.K., Naik, S.N., 2009. Long-term storage stability of biodiesel produced from Karanja oil. Fuel. 88(11), 2315-2318.

[23] Davis, S.C., Anderson-Teixeira, K.J., De Lucia, E.H., 2008. Life-cycle analysis and the ecology of Biofuels. Trends Plant Sci. 14(3), 140-146.

[24] de Souza, S.P., Pacca, S., de Ávila, M.T., Borges, J.L.B., 2010. Greenhouse gas emissions and energy balance of palm oil biofuel. Renew. Energ. 35(11), 2552-2561.

[25] Deshmukh, S.J., Bhuyar, L.B., 2009. Transesterified Hingan (Balanites) oil as a fuel for compression ignition engines. Biomass Bioenergy. 33(1), 108-112.

[26] de Oliveira, M.E.D., Vaughan, B.E., Rykeil, E.J., 2005. Ethanol as fuel: energy, carbon dioxide balances, and ecological footprint. BioScience. 55(7), 593-602.

[27] Diwani, G.E., Attia, N.K., Hawash, S.I., 2009. Development and evaluation of biodiesel fuel and byproducts from Jatropha oil. Int. J. Environ. Sci. Technol. 6(2), 219-224.

[28] Djomo, S.N., Humbert, S., Blumberga, D., 2008. Life cycle assessment of hydrogen produced from potato steam peels. Int. J. Hydrogen Energy. 33(12), 3067-3072.
[29] Djomo, S.N., Blumberga, D., 2011. Comparative life cycle assessment of three biohydrogen pathways. Bioresour. Technol. 102(3), 2684-2694.

[30] Doornbosch, R., Steenblik, R., 2007. Biofuels. Is the cure worse than the disease?. OECD SG/SD/RT 2007-3, Paris.

[31] Dreier, T., Tzscheutschler, P., 2001. Ganzheitliche Systemanalyse für die Erzeugung und Anwendung von Biodiesel und Naturdiesel im Verkehrssektor. Bayerisches Staatsministerium für Landwirtschaft und Forsten, Gelbes Heft 72, München.

[32] Dressler, D., Loewen, A., Nelles, M., 2012. Life cycle assessment of the supply and use of bioenergy: impact of regional factors on biogas production. Int. J. Life Cycle Assess. 17, 1104-1115.

[33] EC-Directive, 2009. Directive 2009/28/EC of The European Parliament and of The Council of 23 April 2009 on the promotion of the use of energy from renewable sources and amending and subsequently repealing Directives 2001/77/EC and 2003/30/EC. Official Journal of the European Union.

[34] Ecobilan PwC, 2002. Bilans énergétiques et gaz à effet de serre des filières de production de biocarburants. Technical report, Final version, November 2002. Prepared for ADEME/ DIREM, by Ecobilan PwC, Neuilly-sur-Seine, France.

[35] Edwards, R., Larive, J-F., Mahieu, V., Rouveirolles, P., 2007. Well-to-wheels analysis of future automotive fuels and powertrains in the European context, version 2c. European Commission Joint Research Centre, Concawe and EUCAR.

[36] Elsayed, M.A., Matthews, R., Mortimer, N.D., 2003. Carbon and Energy Balances for a Range of Biofuels Options. Project No. B/B6/00784/REP, URN 03/836, Sheffield Hallam University, Resources Research Unit.

[37] Emmenegger, M.F., Pfister, S., Koehler, A., de Giovanetti, L., Arena, A.P., Zah, R., 2011. Taking into account water use impacts in the LCA of biofuels: an Argentinean case study. Int. J. Life Cycle Assess. 16, 869-877.

[38] Escobar, J.C., Lora, E.S., Venturini, O.J., Yanez, E.E., Castillo, E.F., Almazan, O., 2009. Biofuels: Environment, technology and food Security. Renew. Sust. Energy Rev. 13(6-7), 1275- 1287

[39] Fargione, J., Hill, J., Tilman, D., Polasky, S., Hawthorne, P., 2008. Land clearing and the biofuel carbon debt. Science. 319, 1235 1238 .

[40] Farrell, A.E., 2008. Biofuels and greenhouse gases: a view from California. GBEP 2nd TF Meeting on GHG Methodologies, Washington.

[41] Felten, D., Fröba, N., Fries, J., Emmerling, C., 2013. Energy balances and greenhouse gas mitigation potentials of bioenergy cropping systems (Miscanthus, rapeseed, and maize) based on farming conditions in Western Germany. Renew. Energ. 55(13), $160-174$

[42] Ferreira, A.F., Ortigueira, J., Alves, L., Gouveia, L., Moura, P. Silva, C.M., 2013. Energy requirement and $\mathrm{CO}_{2}$ emissions of bioH production from microalgal biomass. Biomass Bioenergy. 49, 249 259 .

[43] Ferreira, A.F., Ribau, J.P., Silva, C.M., 2011. Energy consumption and $\mathrm{CO}_{2}$ emissions of potato peel and sugarcane biohydrogen production pathways, applied to Portuguese road transportation. Int. J. Hydrogen Energy. 36(21), 13547-13558

[44] Finco, A., Bentivoglio, D., Rasetti, M., Padella, M., Cortesi, D. Polla, P., 2012. Sustainability of rapeseed biodiesel using life cycle assessment. Presentation at the international association of agricultural economists (IAAE) triennial conference, Foz do Iguaçu, Brazil.

[45] Fore, S.R., Porter, P., Lazarus, W., 2011. Net energy balance of small-scale on-farm biodiesel production from canola and soybean. Biomass Bioenergy. 35(5), 2234-2244.

[46] Gardy, J., Hassanpour, A., Lai, X., Rehan, M., 2014. The influence of blending process on the quality of rapeseed oil-used cooking oil biodiesels. Int. Sci. J. Environ. Sci. 3, 233-240.

[47] Glenister, D., Nunes, V., 2011. Understanding sustainable biofuels production, the EU renewable energy directive and international initiatives to verify sustainability - A discussion about the global importance of ensuring biofuels are produced sustainably and the 
international initiatives to drive the market in a sociality accettable and environmentally friendly well-managed direction", White Paper, Systems and Services Certification, SGS.

[48] Gnansounou, E., Dauriat, A., 2004. Etude Comparative de Carburants par Analyse de Leur Cycle de Vie. Swiss Federal Institute of Technology of Lausanne. Laboratory of Energy Systems (LASEN), Reports. 415.105:2002 and 420.100:2004, prepared for Alcosuisse.

[49] Gnansounou, E., Dauriat, A., Panichelli, L., Villegas, J.D., 2009. Estimating energy and green house gas balance of various biofuel: concept and Methodologies; working paper. EPFL-ENAC-LASEN.

[50] Gnansounou, E., Dauriat, A., Villegas, J., Panichelli, L., 2009. Life cycle assessment of biofuels: Energy and greenhouse gas balances. Bioresour. Technol. 100(21), 4919-4930.

[51] González-García, S., Moreira, M.T., Feijoo, G., 2010. Comparative environmental performance of lignocellulosic ethanol from different feedstocks. Renew. Sust. Energy Rev. 14(7), 2077-2085.

[52] González-García, S., Moreira, M.T., Feijoo, G., 2012. Environmental aspects of eucalyptus based ethanol production and use. Sci. Total Environ. 438, 1-8.

[53] Gracia, C.A., Fuentes, A., Hennecke, A., Riegelhaupt, E., Manzini, F., Masera, O., 2011. Life Cycle greenhouse gas emission and energy balances of sugarcane ethanol production in Mexico. Appl. Energy. 88(6), 2088-2097.

[54] Groode, T.A., Heywood, J.B., 2007. Ethanol: a look ahead. MIT publication, Cambridge, MA, USA.

[55] Güereca, L.P., Gassó, S., Baldasano, J.M., Jiménez-Guerrero, P., 2006. Life cycle assessment of two biowaste management systems for Barcelona, Spain. Resour. Conserv. Recycl. 49(1), 32-48.

[56] Hahn-Hägerdal, B., Galbe, M., Gorwa-Grauslund, M.F., Lidén, G., Zacchi, G., 2009. Bioethanol-the fuel of tomorrow from the residues of today. Trends Biotechnol. 24, 549-556.

[57] Hallenbeck, P.C., Benemann, J.R., 2002. Biological hydrogen production; fundamentals and limiting processes. Int. J. Hydrogen Energy. 27(11-12), 1185-1193.

[58] Hartmann, J.K., 2006. Life-cycle-assessment of industrial scale biogas plants. Dissertation, zur Erlangung des Doktorgrades, der Fakultät für Agrarwissenschaften, der Georg-August-Universität Göttingen.

[59] Hill, J., Nelson, E., Tilman, D., Polasky, S., Tiffany, D., 2006. Environmental, economic, and energetic costs and benefits of biodiesel and ethanol biofuels. Proc. Natl. Acad. Sci. 103, 11206-11210.

[60] Hong, Y., Nizami, A.S., Pourbafrani, M., Saville, B.A., MacLean, H.L., 2013. Impact of cellulase production on environmental and financial metrics for lignocellulosic ethanol. Biofuels, Bioprod. Biorefin. 7(3), 303-313.

[61] Huber, G.W., Iborra, S., Corma, A., 2006. Synthesis of transportation fuels from biomass: chemistry, catalysts, and engineering. Chem. Rev. 106(9), 4044-4098.

[62] IPCC, 2011. Summary for Policymakers, in: Edenhofer, O., Pichs-Madruga, R., Sokona, Y., Seyboth, K., Matschoss, P., Kadner, S., Zwickel, T., Eickemeier, P., Hansen, G., Schlömer, S., von Stechow C. (Eds.), IPCC special report on renewable energy sources and climate change mitigation. Cambridge University Press, Cambridge, United Kingdom and New York, NY, USA.

[63] Janulis, P., 2004. Reduction of energy consumption in biodiesel fuel life cycle. Renew. Energ. 29(6), 861-871.

[64] Jungbluth, N., Büsser, S., Frischknecht, R., Tuchschmid, M., 2008. Life cycle assessment of biomass-to-liquid fuels. Draft Report. ESU Services GmbH, Uster, Germany.

[65] Jury, C., Benetto, E., Koster, D., Schmitt, B., Welfring, J., 2010. Life Cycle Assessment of biogas production by monofermentation of energy crops and injection into the natural gas grid. Biomass Bioenergy. 34(1), 54-66.

[66] Kalinci, Y., Hebasli, A., Dincer, I., 2012. Life cycle assessment of hydrogen production from biomass gasification systems. Int. J. Hydrogen Energy. 37(19), 14026-14039.

[67] Kamahara, H., Hasanudin, U., Widiyanto, A., Tachibana, R., Atsuta, Y., Goto, N., Daimon, H., Fujie, K., 2010. Improvement potential for net energy balance of biodiesel derived from palm oil: a case study from Indonesian practice. Biomass Bioenergy. 34(12), 1818-1824.
[68] Kauffman, N.S., Hayes, D.J., 2013. The trade-off between bioenergy and emissions with land constraints. Energy Policy. 54, 300-310.

[69] Keller, D., Wahnschaffe, U., Rosner, G., Mangelsdorf, I., 1998. Considering human toxicity as an impact category in Life Cycle Assessment. Int. J. Life Cycle Assess. 3(2), 80-85.

[70] Kesari, V., Rangan, L., 2010. Development of Pongamia pinnata as an alternative biofuel. Crop - current status and scope of plantations in India. J. Crop Sci. Biotechnol. 13(3), 127-137.

[71] Khan, S.A., Rashmi, H.M.Z., Prasad, S., Banerjee, U.C., 2009 Prospects of biodiesel production from microalgae in India. Renew. Sust. Energy Rev. 13(9), 2361-2372.

[72] Khanna, M., Scheffran, J., Ziberman, D., 2010. Handbook of bioenergy economics and policy. Springer Science and Business Media.

[73] Kiatkittipong, W., Wongsuchoto, P., Pavasant, P., 2009. Life cycle assessment of bagasse waste management options. Waste Manage. 29(5), 1628-1633

[74] Kim, S., Dale, B.E., 2005. Environmental aspects of ethanol derived from no tilled corn grain: non-renewable energy consumption and greenhouse gas emissions. Biomass Bioenergy. 28(5), 475-489.

[75] Kim, S., Dale, B.E., 2009. Regional variations in greenhouse gas emissions of biobased products in the United States-corn based ethanol and soybean oil. Int. J. Life Cycle Assess. 14(6), 540-546.

[76] Kim, S., Dale, B.E., 2004. Global potential bioethanol production from wasted crops and crop residues. Biomass Bioenergy. 26(4), 361-375.

[77] Kim, S.J., Jung, S.M., Park, Y.C., Park, K., 2007. Lipase catalyzed transesterification of soybean oil using ethyl acetate, an alternative acyl acceptor. Biotechnol. Bioprocess Eng. 12(4), 441-445.

[78] Koga, N., Kajiyama, T., Senda, K., Iketani, S., Tsuda, S., 2013 Energy efficiency of potato production practices for bioethano feedstock in northern Japan. Eur. J. Agron. 44, 1-8.

[79] Korres, N.E., Singh, A., Nizami, A.S., Murphy, J.D., 2010. Is grass biomethane a sustainable transport biofuel. Biofuels, Bioprod Biorefin. 4(3), 310-325.

[80] Korres, N.E., Thamsiriroj, T., Smyth, B.M., Nizami, A.S., Singh. A., Murphy, J.D., 2011. Grass biomethane for agriculture and energy. in: Lichtfouse, E. (Ed.), Genetics, biofuels and local farming systems, sustainable agriculture reviews. Springer Science and Business Media B.V., pp. 5-49.

[81] Lange, M., 2011. The GHG balance of Biofuels taking into account land use changes. Energy Policy. 39(5), 2373-2385

[82] Lankoski, J., Ollikainen, M., 2011. Biofuel policies and the environment: Do climate benefits warrant increased production from biofuel feedstocks. Ecol. Econ. 70(4), 676-687.

[83] Lardon, L., Helias, A., Sialve, B., Steyer, J.P., Bernard, O., 2009. Life-cycle assessment of biodiesel production from microalgae. Environ. Sci. Technol. 43(17), 6475-6481

[84] Le Quéré, C., Raupach, M., Canadell, J., Marland, G., Bopp, L., Ciais, P., Conway, T., Doney, S., Feely, R., Foster, P., Friedlingstein, P., Gurney, K., Houghton, R., House, J., Huntingford, C., Levy, P., Lomas, M., Majkut, J., Metzl, N., Ometto, J.P., Peters, I., Prentice, C., Randerson, J., Running, S., Sarmiento, J., Schuster, U., Sitch, S., Takahashi, T., Viovy, N., van der Werf, G., Woodward, F., 2009. Trends in the sources and sinks of carbon dioxide. Nat. Geosci. 2, 831-836

[85] Lechón, Y., Cabal, H., Lago, C., de la Rua, C., Sáez, R., Fernández. M., 2005. Análisis del ciclo de vida de combustibles alternativos para el transporte. Fase I. Análisis de ciclo de vida comparativo de etanol de cereales y de la gasolina. Energía y Cambio Climático. Ed. Centro de Publicaciones Secretaría General Técnica Ministerio de Medio Ambiente, Madrid.

[86] Lechón, Y., Cabal, H., de la Rúa, C., Lago, C., Izquierdo, L., Sáez. R., 2010. Life cycle environmental aspects of biofuel goals in Spain. Scenarios. 15th European Biomass Conference and ExhibitionFrom Research to Market Deployment. 7-11. May 2007, Berlin.

[87] Ledford, H., 2006. Liquid fuel synthesis: Making it up as you go along. Nature. 444, 677-678. 
[88] Levin, D.B., Pitt, L., Love, M., 2004. Biohydrogen production: prospects and limitations to practical application. Int. J. Hydrogen Energy. 29(2), 173-185.

[89] Liska, A.J., Cassman, K.G., 2008. Towards standardization of lifecycle metrics for biofuels: Greenhouse gas emissions mitigation and net energy yield. J. Biobased Mater. Bioenergy. 2, 187-203.

[90] Long, Y.D., Guo, F., Fang, Z., Tian, X.F., Jiang, L.Q., Zhang, F., 2011. Production of biodiesel and lactic acid from oil using sodium silicate as catalyst. Bioresour. Technol. 102, 6884-6886.

[91] Luo, L., van der Voet, E., Huppes, G., Udo de Haes, H.A., 2010. Allocation issues in LCA methodology: A case study of corn stoverbased fuel ethanol. Int. J. Life Cycle Assess. 14, 529-539.

[92] Luo, D., Hu, Z., Choi, D.G., Thomas, V.M., Realff, M.J., Chance, R.R., 2010. Life cycle energy and greenhouse gas emissions for an ethanol production process based on blue-green algae. Environ. Sci. Technol. 44(22), 8670-8677.

[93] Macedo, I.C., Seabra, J.E.A., Silva, J.E.A.R., 2008. Greenhouse gases emissions in the production and use of ethanol from sugarcane in Brazil: the 2005/2006 averages and a prediction for 2020. Biomass Bioenergy. 32(7), 582-595.

[94] Macedo, I.D.C., 1998. Greenhouse gas balance and energy balance in bioethanol production and utilization in Brazil. Biomass Bioenergy. 14, $77-81$.

[95] Malca, J., Freire, F., 2006. Renewability and life cycle energy efficiency of bioethanol and bio-ethyl tertiary butyl ether (bio ETBE): assessing the implication of allocation. Energy. 31, 3362-3380.

[96] Manish, S., Banerjee, R., 2008. Comparison of biohydrogen production processes. Int. J. Hydrogen Energy. 33, 279-286.

[97] Martinsen, D., Funk, C., Linssen, J., 2010. Biomass for transportation fuels-A cost effective option for the German energy supply?. Energy Policy. 38(1), 128-140.

[98] Macedo, I.M.R., Lima, V., Leal, J.E., da Silva, A.R., 2004. Assessment of greenhouse gas emissions in the production and use of fuel ethanol in Brazil. Government of the State of São Paulo, São Paulo, Brazil.

[99] Menichetti, E., Otto, M., 2009. Energy balance and greenhouse gas emissions of biofuels from a life-cycle perspective. In: Howarth R.W., Bringezu, S. (Eds.), Biofuels: Environmental Consequences and Interactions with Changing Land Use. Proceedings of the Scientific Committee on Problems of the Environment (SCOPE) International Biofuels Project Rapid Assessment, Ithaca NY, Cornell University, USA, pp. 81-109.

[100] Monti, A., Fazio, S., Venturi, G., 2009. Cradle-to-farm gate life cycle assessment in perennial energy crops. Eur. J. Agron. 31(2), 77-84.

[101] Mukherjee, P., Varshney, A., Johnson, S., Jha, T.B., 2011. Jatropha curcas: a review on biotechnological status and challenges. Plant Biotechnol. Rep. 5(3), 197-215.

[102] Murphy, J.D., Browne, J., Allen, E., Gallagher, C., 2013. The resource of biomethane, produced via biological, thermal and electrical routes, as a transport biofuel. Renew. Energ. 55, 474-479.

[103] Myhre, G., Shindell, D., Breon, F., Collins, W., Fuglestvedt, J., Huang, J., Koch, D., Lamarque, J.F., Lee, D., Mendoza, B., Nakajima, T., 2013. Anthropogenic and natural radiative forcing. Clim. Change. 423.

[104] Nabi, M.N., Akhter, M.S., Shahadat, M.M.Z., 2006. Improvement of engine emissions with conventional diesel fuel and diesel-biodiesel blends. Bioresour. Technol. 97(3), 372-378.

[105] Najafi, G., Ghobadian, B., Tavakoli, T., Yusaf, T., 2009. Potential of bioethanol production from agricultural wastes in Iran. Renew. Sust. Energy Rev. 13(6-7), 1418-1427.

[106] Ndong, R., Montrejaud-Vignoles, M., Girons, O.S., Gabrielle, B., Pirot, R., Domergue, M., Sablayrolles, C., 2009. Life cycle assessment of biofuels from Jatropha curcas in West Africa: a field study. GCB Bioenergy. 1(3), 197-210

[107] Nguyen, T.L.T., Gheewala, S.H., Garivait, S., 2007. Fossil energy savings and GHG mitigation potentials of ethanol as a gasoline substitute in Thailand. Energy Policy. 35(10), 5195-5205.

[108] Nizami, A.S., Ismail, I.M.I., 2013. Life cycle assessment of biomethane from lignocellulosic biomass, in: Life cycle assessment of renewable energy sources. Green Energy and Technology book series, Springer-Verlag London Ltd. pp. 79-94.
[109] Nizami, A.S., Ouda, O.K.M., Rehan, M., El-Maghraby, A.M.O., Gardy, J., Hassanpour, A., Kumar, S., Ismail, I.M.I., 2015a. The potential of Saudi Arabian natural zeolites in energy recovery technologies. Energy. 1-10. doi:10.1016/j.energy.2015.07.030

[110] Nizami, A.S., Rehan, M., Ouda, O.K.M., Shahzad, K., Sadef, Y., Iqbal, T., Ismail, I.M.I., 2015b. An argument for developing wasteto-energy technologies in Saudi Arabia. Chem. Eng. 45, 337-342.

[111] OECD-FAO., 2015. AgriculturaL Outlook., 2015-2024.

[112] Nizami, A.S., Shahzad, K., Rehan, M., Ouda, O.K.M., Khan, M.Z., Ismail, I.M.I., Almeelbi, T., Basahi, J.M., Demirbas, A. 2016. Developing waste biorefinery in Makkah: a way forward to convert urban waste into renewable energy. Appl. Energy. DOI: 10.1016/j.apenergy.2016.04.116

[113] Ouda, O.K.M., Raza, S.A., Nizami, A.S., Rehan, M., Al-Waked, R., Korres, N.E., 2016. Waste to energy potential: A case study of Saudi Arabia. Renew. Sust. Energy Rev. 61, 328-340

[114] Nzihou, A., Flamant, G., Stanmore, B., 2012. Synthetic fuels from biomass using concentrated solar energy. Energy. 42(1), 121-131.

[115] Pande, M., Bhaskarwar, A.N., 2012. Biomass conversion to energy, in: Baskar, C., Baskar, S., Dhillon, R.S. (Eds.), Biomass Conversion. Springer-Verlag Berlin Heidelberg.

[116] Papong, S., Malakul, P., 2010. Life cycle energy and environmental analysis of bioethanol production from cassava in Thailand. Bioresour. Technol. 101(1), S112-S118.

[117] Patterson, T., Esteves, S., Dinsdale, R., Maddy, J., 2013. Life cycle assessment of biohydrogen and biomethane productionand utilisation as a vehicle fuel. Bioresour. Technol. 131, 235-245.

[118] Paul, N., Kemnitz, D., 2006. Biofuels- Plant raw materials, Products. Fachagentur, Nachwachsende Rohstoffe eV (FNR), WPR communications, Berlin, 43.

[119] Pehnelt, G., Vietze, C., 2013. Recalculating GHG emissions saving of palm oil biodiesel. Environ. Dev. Sust. 15, 429-479.

[120] Pimentel, D., Patzek, T.W., 2005. Ethanol production using corn, switchgrass, and wood, biodiesel production using Soybean and Sunflower. Nat. Resour. Res. 14(1), 65-76.

[121] Popp, J., Lakner, Z., Harangi-Rákos, M., Fári, M., 2014. The effect of bioenergy expansion: Food, energy, and environment. Renew. Sust. Energy Rev. 32, 559-578

[122] Pradhan, A., Shrestha, D.S., Van Gerpen, J., Duffield, J., 2008. The energy balance of soybean oil biodiesel production: a review of past studies. Trance. ASABE. 51(1), 185-194.

[123] Prasad, S., Singh, A., Jain, N., Joshi, H.C., 2007a. Ethanol production from sweet sorghum syrup for utilization as automotive fuel in India. Energy Fuels. 21(4), 2415-2420.

[124] Prasad, S., Singh, A., Joshi, H.C., 2007b. Ethanol as an alternative fuel from agricultural, industrial and urban residues. Resour. Conserv. Recycl. 50(1), 1-39.

[125] Quirin, M., Gärtner, S., Pehnt, M., Reinhardt, G., 2004. CO2 mitigation through biofuels in the transport sector. Main report, IFEU, Heidelberg.

[126] Rehan, M., Nizami, A.S., Shahzad, K., Ouda, O.K.M., Ismail, I.M.I., Almeelbi, T., Iqbal T., Demirbas, A., 2016. Pyrolytic liquid fuel: a source of renewable energy in Makkah. Energy Sources, Part A: Recovery, Utilization, and Environmental Effects. DOI:10.1080/15567036.2016.1153753

[127] Rashid, U., Anwar, F., 2008. Production of biodiesel through basecatalyzed transesterification of sunflower oil using an optimized protocol. Energy Fuels. 22(2), 1306-1312.

[128] Rathore, D., Singh, A., 2013. Biohydrogen Production from Microalgae, in: Gupta, V.K., Tuohy, M.G. (Eds.), Biofuel Technologies. Springer-Verlag Berlin Heidelberg.

[129] Rathore, D., Pant, D., Singh, A., 2013. A comparison of life cycle assessment studies of different biofuels, in: Singh, A., Pant, D. Olsen, S.I. (Eds.), Life Cycle Assessment of Renewable Energy Sources. Green Energy and Technology Series, Springer-Verlag London, pp. 269-289.

[130] Reijnders, L., 2008. Ethanol production from crop residues and soil organic carbon. Resour Conserv. Recycl. 52(4), 653-658. 
[131] Reinhardt, G.A., Gärtner, S., Rettenmaier, N., Münch, J., Falkenstein., E.V., 2007. Screening life cycle assessment of Jatropha, Germany.

[132] REN21. 2009. Renewables Global Status Report: 2009 Update (Paris: REN21 Secretariat).

[133] Renouf, M.A., Wegener, M.K., Nielsen, L.K., 2008. An environmental life cycle assessment comparing Australian sugarcane with US corn and UK sugar beet as producers of sugars for fermentation. Biomass Bioenergy. 32(12), 1144-1155.

[134] RFA. 2009. Ethanol Industry Outlook, Renewable Fuels Association.

[135] RFA. 2016. Fueling a high octane future. Ethanol Industry Outlook. Renewable Fuels Association.

[136] Romagnoli, F., Blumberga, D., Pilicka, I., 2011. Life cycle assessment of biohydrogen production in photosynthetic processes. Int. J. Hydrogen Energy. 36(13), 7866-7871.

[137] Rosenberger, A., Kaul, H.P., Senn, T., Aufhammer, W., 2001. Improving the energy balance of bioethanol production from winter cereals: the effect of crop production intensity. Appl. Energy. 68(1), 51-67.

[138] Sadaf, Y., Nizami, A.S., Batool, S.A., Chaudhary, M.N., Ouda, O.K.M., Asam, Z.Z., Habib, K., Rehan, M., Demibras, A., 2016. Waste-to-energy and recycling value for developing integrated solid waste management plan in Lahore. Energy Sources. Part B: Economics, Planning, and Policy.

[139] Sander, K., Murthy, G.S., 2010. Life cycle analysis of algae biodiesel. Int. J. Life Cycle Assess. 15, 704-714.

[140] Sassner, P., Galbe, M., Zacchi, G., 2008. Techno-economic evaluation of bioethanol production from three different lignocellulosic materials. Biomass Bioenergy. 32(5), 422-430.

[141] Sawayama, S., Minowa, T., Yokoyama, S-Y., 1999. Possibility of renewable energy production and $\mathrm{CO}_{2}$ mitigation by thermochemical liquefaction of microalgae. Biomass Bioenergy. 17(1), 33-39.

[142] Scholz, V., da Silva, J.N., 2008. Prospects and risks of the use of castor oil as a fuel. Biomass Bioenergy. 32(2), 95-100.

[143] Searchinger, T., Heimlich, R., Houghton, R.A., 2008. Use of US croplands for biofuels increases greenhouse gases through emissions from land-use change. Science. 319, 1238-1140.

[144] Sharma, V., Ramawat, K.G., Choudhary, B.L., 2012. Biodiesel Production for Sustainable Agriculture, in: Lichtfouse, E. (Ed.), Sustainable Agriculture Reviews. Sust. Agric. Rev. pp, 133-160.

[145] Sheehan, J., Aden, A., Paustian, K., Killian, K., Brenner, J., Walsh, M., Nelson, R., 2004. Energy and environmental aspects of using corn stover for fuel ethanol. J. Ind. Ecol. 7, 117-146.

[146] Sheehan, J., Camobreco, V., Duffield, J., Graboski, M., Shapouri, H., 1998. Life cycle inventory of biodiesel and petroleum diesel for use in an urban bus. NREL/SR-580-24089. Golden, Colo. National Renewable Energy Laboratory.

[147] Sims, R.E.H., Mabee, W., Saddler, J.N., Taylor, M., 2010. An overview of second generation biofuel technologies. Bioresour. Technol. 101(6), 1570-1580.

[148] Singh, A., Murphy, J.D., 2009. Biomethane from animal waste and grass for clean vehicular biofuel in Ireland. Twelfth International Waste Management and Landfi 11 Symposium, CISA, Environmental Santiary Engineering Centre, Italy Cagliari, Sardinia, Italy.

[149] Singh, A., Nizami, A.S., Korres, N.E., Murphy, J.D., 2011. The effect of reactor design on the sustainability of grass biomethane. Renew. Sust. Energy Rev. 15(3), 1567-1574.

[150] Singh, A., Pant, D., Olsen, S.I., Nigam, P.S., 2012. Key issues to consider in microalgae based biodiesel production. Energy Educ. Sci. Technol. Part A Energy Sci. Res. 29(1), 563-576.

[151] Singh, A., Smyth, B.M., Murphy, J.D., 2010a. A biofuel strategy for Ireland with an emphasis on production of biomethane and minimization of land take. Renew. Sust. Energy Rev. 14(1), 277-288.

[152] Singh, A., Pant, D., Korres, N.E., Nizami, A.S, Prasad, S., Murphy, J.D., 2010b. Key issues in life cycle assessment of ethanol production from lignocellulosic biomass: Challenges and perspectives. Bioresour. Technol. 101(13),5003-5012.

[153] Smyth, B.M., Murphy, J.D., O'Brien, C., 2009. What is the energy balance of grass biomethane in Ireland and other temperate northern European climates?. Renew. Sust. Energy Rev. 13(9), 2349-2360.
[154] Spatari, S., Zhang, Y., MacLean, H.L., 2005. Life cycle assessment of switchgrass- and corn stover-derived ethanol-fueled automobiles. Environ. Sci. Technol. 39 (24), 9750-9758.

[155] Stephenson, A.L., Kazamia, E., Dennis, J.S., Howe, C.J., Scott, S.A., Smith, A.G., 2010. Life-cycle assessment of potential algal biodiesel pro-duction in the United Kingdom: a comparison of raceways and air-lift tubular bioreactors. Energy Fuels. 24(7), 4062-4077.

[156] Stichnothe, H., Azapagic, A., 2009. Bioethanol from waste: life cycle estimation of the greenhouse gas saving potential. Resour. Conserv. Recycl. 53 (11), 624-630.

[157] Tahir, M.S., Shahzad, K., Shahid, Z., Sagir, M., Rehan, M. Nizami, A.S., 2015. Producing methane enriched biogas using solvent absorption method. Chem. Eng. Trans. 45,1309-1314.

[158] Thyø, K.A., Wenzel, H., 2007. Life Cycle Assessment of biogas from maize silage and from manure - for transport and for heat and power production under displacement of natural gas based heat works and marginal electricity in northern Germany. 2nd draft report for Xergi A/S Sofiendalsvej 7, 9200 Aalborg SV.

[159] Unnasch, S., Pont, J., Hooks, M., Chan, M., Waterland, L., Rutherford, D., 2007. Full fuel cycle assessment: well to wheels energy inputs, emissions, and water impacts. Consultant Report prepared by TIAX LLC for California Energy Commission, Cupertino CA, USA.

[160] United States - Energy Information Administration (US-EIA), 2016.

[161] UNICA; Brazilian Sugarcane Industry Association, 2009. Mexico requests unica to lead technical mission to discuss ethanol.

[162] van Vliet, O.P., Faaij, A.P., Turkenburg, W.C., 2009. FischerTropsch diesel production in a well-to-wheel perspective: a carbon, energy flow and cost analysis. Energy Convers. Manage. 50, 855876.

[163] Veeraraghavan, S., Riera-Palou, X., 2006. Well-to wheel performance of Iogen lignocellulosic ethanol. Shell Global Solutions International.

[164] Vogt, R., 2008a. Basisdaten, zu THG-Bilanzen für BiogasProzessketten und Erstellung neuer THG Bilanzen. Institut für Energie- und Umweltforschung Heidelberg $\mathrm{GmbH}$.

[165] Vogt, R., 2008b. Optimierungen für einen nachhaltigen Ausbau der Biogaserzeugung und nutzung in Deutschland.

[166] World Watch Institute (WWI), 2006. Biofuels for transportation, global potential and implications for sustainable agriculture and energy in the 21st century. Submited report prepared for BMELV in cooperation with GTZ and FNR

[167] Xin, J., Imahara, H., Saka, S., 2009. Kinetics on the oxidation of biodiesel stabilized with antioxidant. Fuel. 88(2), 282-286.

[168] Yáñez Angarita, E.E., Silva Lora, E.E., da Costa, R.E., Torres, E.A., 2009. The energy balance in the palm oil-derived methy ester (PME) life cycle for the cases in Brazil and Colombia Renew. Energ. 34(12), 2905-2913.

[169] Zah, R., Böni, H., Gauch, M., Hischier, R., Lehmann, M., Wäger, P., 2007. Ökobilanz von Energieprodukten: Ökologische Bewertung von Biotreibstoffen. EMPA, St. Gallen, Switzerland.

[170] Zhang, X., Yan, S., Tyagi, R.D., Surampalli, R.Y., 2013. Energy balance and greenhouse gas emissions of biodiesel production from oil derived from wastewater and wastewater sludge. Renew. Energ. $55,392-403$.

[171] Zhi Fu, G., Chan, A.W., Minns, D.E., 2003. Life cycle assessment of bio-ethanol derived from cellulose. Int. J. Life Cycle Assess. 8(3), 137-141.

[172] Zhu, H., Beland, M., 2006. Evaluation of alternative methods of preparing hydrogen producing seeds from digested wastewater sludge. Int. J. Hydrogen Energy. 31(14), 1980-1988 